\title{
Giardia duodenalis Infections in Humans and Other Animals in China
}

\author{
Junqiang $\mathrm{Li}^{\dagger}$, Haiyan Wang ${ }^{\dagger}$, Rongjun Wang and Longxian Zhang * \\ College of Animal Science and Veterinary Medicine, Henan Agricultural University, Zhengzhou, China
}

Giardia duodenalis is an important zoonotic pathogen in both public and veterinary health, and has been genotyped into at least eight assemblages $(A-H)$, each with a distinct host range. In recent years, this intestinal protozoan parasite has been identified widely in humans and various other animals, and has even been recorded in environmental contaminants. Along with whole genome sequencing of $G$. duodenalis, multilocus sequence typing is increasingly being used to characterize $G$. duodenalis isolates. Here, we review the epidemiology, genotyping, and subtyping of $G$. duodenalis from humans and a wide range of other animals, as well as from wastewater, in China.

OPEN ACCESS

Edited by:

Guan Zhu,

Texas A\&M University, United States

Reviewed by:

Federica Berrilli,

Università degli Studi di Roma Tor

Vergata, Italy

Anjan Debnath,

University of California, San Diego,

United States

*Correspondence:

Longxian Zhang

zhanglx8999@henau.edu.cn

zhanglx8999@gmail.com

${ }^{\dagger}$ These authors have contributed equally to this work.

Specialty section:

This article was submitted to

Infectious Diseases,

a section of the journal

Frontiers in Microbiology

Received: 03 June 2017 Accepted: 29 September 2017

Published: 13 October 2017

Citation:

Li J, Wang H, Wang R and Zhang L (2017) Giardia duodenalis Infections in Humans and Other Animals in China.

Front. Microbiol. 8:2004.

doi: 10.3389/fmicb.2017.02004
Keywords: G. duodenalis, humans, animals, prevalence, assemblage, multilocus sequence typing, China, zoonotic

\section{INTRODUCTION}

Giardia is one of the most common intestinal parasites of both humans and a diverse range of other animals (Feng and Xiao, 2011). The parasite was first discovered by Antonie van Leeuwenhoek over 300 years ago (Dobell, 1920), and since then, six Giardia species have been described. Among them, Giardia agilis, Giardia ardeae, Giardia psittaci, Giardia muris, and Giardia microti infect animals ranging from amphibians to rodents and birds, whereas the broad range of hosts for Giardia duodenalis (syn. Giardia intestinalis and Giardia lamblia) includes humans and domestic, farmed, and wild animals (Monis et al., 2009; Feng and Xiao, 2011; Ryan and Cacciò, 2013). Giardiasis, which is caused by Giardia duodenalis, is an important zoonotic disease for both public and veterinary health (Ryan and Cacciò, 2013).

The G. duodenalis life cycle is simple in that it comprises rapidly multiplying trophozoites (attached to intestinal epithelial cells) and cysts that are resistant to environmental degradation, which are excreted with feces and transmitted onwards via the fecal-oral route (Lv et al., 2013; Einarsson et al., 2016). G. duodenalis has long been considered to reproduce asexually by simple binary fission, but there is increasing evidence from epidemiological, molecular genetics, and whole genome sequencing studies that Giardia is capable of sexual reproduction (Cooper et al., 2007; Morrison et al., 2007; Poxleitner et al., 2008; Nolan et al., 2010; Gabín-García et al., 2017).

Molecular biological analysis of $G$. duodenalis has benefited from understanding the taxonomy, population genetics, and epidemiology of this pathogen, and such studies are essential to the effective control of giardiasis in clinical practice (Cacciò and Ryan, 2008). In terms of its genetic variation, $G$. duodenalis isolates genotypically fall into one of at least eight assemblages (A-H), each of which have a distinct host range (Cacciò and Ryan, 2008; Sprong et al., 2009; Feng and Xiao, 2011; Ryan and Cacciò, 2013). There is also genetic diversity within these assemblages. For example, subassemblages AI, AII, and AIII fall within assemblage A (Feng and Xiao, 2011) and BIII and BIV form assemblage B (Monis et al., 2003), while various sub-assemblages form assemblage E (Zhang et al., 2012c).

Multilocus genotyping (MLG) analysis using both conserved (e.g., ssrDNA, ef, $h 2 b, h 4$ ) and variable (e.g., $t p i, g d h, b g$ ) genes was originally used to assess the G. duodenalis assemblages 
(Wielinga et al., 2011). Nowadays, variable genes such as tpi, $g d h$, and $b g$ are used to characterize $G$. duodenalis isolates from humans and other animals and determine the genotype or subtype. These analyses provide sufficient resolution to assess the disease burden arising from zoonotic transmission of the parasite (Cacciò et al., 2008; Sprong et al., 2009; Wang et al., 2014b; Wang H. et al., 2016). To date, four genetically distinct $G$. duodenalis isolates (WB, AI; AS175, AII; P15, E, and GS, B) have been studied genomically (Franzén et al., 2009; Jerlström-Hultqvist et al., 2010; Adam et al., 2013) and transcriptomically (Franzén et al., 2013). Differences between the genomic and transcriptomic profiling results may explain the differences observed in host preferences and clinical presentation of $G$. duodenalis infection (Franzén et al., 2009, 2013; Jerlström-Hultqvist et al., 2010; Adam et al., 2013).

Annually, 280 million people worldwide are estimated to have clinically diagnosable giardiasis (Feng and Xiao, 2011; Ryan and Cacciò, 2013; Einarsson et al., 2016; Squire and Ryan, 2017), and infection rates are higher in developing countries (Feng and Xiao, 2011; Ryan and Cacciò, 2013). Giardiasis is generally a self-limiting clinical illness characterized by watery diarrhea, abdominal cramps, bloating, weight loss, and malabsorption (Feng and Xiao, 2011; Einarsson et al., 2016). However, asymptomatic infections occur more frequently than symptomatic ones (Himsworth et al., 2010; Feng and Xiao, 2011; Ryan and Cacciò, 2013; Wegayehu et al., 2016). In China, approximately 28.5 million giardiasis cases are estimated to occur in humans per year (Feng and Xiao, 2011), although the true incidence is likely underestimated as there are many undetected and/or unreported cases. In recent years, G. duodenalis has been identified in humans, non-human primates (NHPs), ruminants, companion animals, domestic animals, wildlife, and even in the environment in China (Liu et al., 2011; Wang et al., 2011, 2014b; Li N. et al., 2012; Zhang et al., 2012c; Liu A. et al., 2014; Liu H. et al., 2014; Li J. et al., 2015; Qi et al., 2016a,b; Wang H. et al., 2016). Here, the epidemiology, genotyping, and subtyping of $G$. duodenalis in humans and various other animals in China are summarized and reviewed.

\section{G. DUODENALIS IN HUMANS}

Investigations and case reports on $G$. duodenalis infections in humans are common in China (Table 1). Sporadic reports of human giardiasis have been documented since 1962, although a number of giardiasis cases were recoded in 1983 in Xi'an (Zhang and Li, 1983). The large number of epidemiological investigations conducted at the start of this century suggested that the average infection rate was $0.85 \%(197 / 23,098)$, with the highest infection rate $(9.46 \%, 7 / 74)$ reported by one study carried out in Shanghai (Wang L. et al., 2013). Differences in the observed rates of infection may be due, in part, to the age of the patients. In China, children $<15$ years of age were the most affected, with the peak infection rate occurring in those aged 5-10 years (Yu et al., 1994; Lv et al., 2013). A similar observation was made in Malaysia, where children under 15 years old were more likely to be infected with G. duodenalis (Mohammed Mahdy et al., 2009; Anuar et al., 2014).
Despite its widespread occurrence, molecular epidemiological data for $G$. duodenalis infections in humans from China is limited. According to the few available genotyping studies, both assemblage A (subtypes AI and AII) and B isolates have been found in China, with subtype AII and assemblage B being the dominant genotypes (Yong et al., 2000; Wang et al., 2011; Wang L. et al., 2013; Wang T. et al., 2017). Interestingly, a canidspecific assemblage $C$ strain, which was first identified in Egypt (Soliman et al., 2011), was found in 16 Giardia-positive diarrheal outpatients in Shanghai (Liu H. et al., 2014). MLG analysis of assemblage AII and B isolates from Shanghai identified six and 11 sequence types, respectively (Wang L. et al., 2013). No significant gender-specific association for G. duodenalis infections or assemblage distribution has been reported in China (Liu H. et al., 2014; Wang T. et al., 2017).

\section{G. DUODENALIS IN NHPS}

The prevalence of G. duodenalis infections in NHPs varies markedly between different studies (Table 2). The average rate of infection for NHPs was $4.49 \%(172 / 3,827)$, with the highest rate recorded by a study conducted in Hunan Province $(44.00 \%$, 33/75). However, variability in the feeding habitats, health status, and age of the subjects, as well as differences in the geographic location and diagnostic techniques used in the studies probably contribute to the discrepant infection rates (Li J. et al., 2017).

Thus far, assemblage A, B, and E strains have been identified in NHPs, with assemblage B dominant in China (Karim et al., 2014, 2015). Only one study, from Shaanxi Province, identified an assemblage E isolate in NHPs in China (Du et al., 2015), although an assemblage $\mathrm{E}$ isolate has also been found in a red colobus monkey in western Uganda (Johnston et al., 2010). MLG has also been used for genotyping G. duodenalis in NHPs. Like humans, several assemblage A (subtypes AI and AII) and B (subtype BIV) subtypes have been identified in NHPs, with subtype BIV identified as the dominant subtype (Karim et al., 2014, 2015). A total of 15 MLG genotypes (two known and 13 novel) were reported in one study, although the two known MLG genotypes were not significant from a public health perspective (Karim et al., 2015).

Phylogenetic analysis has suggested the possibility of geographical segregation and host-adaptation amongst assemblage B strains in NHPs in China. The role of NHPs in the transmission of G. duodenalis to humans is not clear. It is believed that the frequent occurrence of assemblage B strains in captive NHPs may be associated with transmission from human sources, or an indication of adaptation to primate host (Sprong et al., 2009; Karim et al., 2015).

\section{G. DUODENALIS IN CATTLE}

In cattle, G. duodenalis infections vary in their prevalence and genotypic distribution according to region and cattle species (Table 3). The first documentation of G. duodenalis infection in dairy cattle occurred in 2006 in Guangdong Province (Xiao et al., 
TABLE 1 | Giardia duodenalis infection rates and genotypes in humans in China.

\begin{tabular}{|c|c|c|c|c|c|c|}
\hline Locations & Patient group & Specimens & Positive (\%) & $\begin{array}{l}\text { Assemblage } \\
\text { (no.) }\end{array}$ & $\begin{array}{l}\text { Subassemblage } \\
\text { (no.) }\end{array}$ & References \\
\hline Shaanxi:Xi'an & Patients & $19^{a}$ & Case reports & & & Zhang and Li, 1983 \\
\hline Anhui & & $10^{\mathrm{a}}$ & Genotypes identified & $\begin{array}{l}A(4) \\
B(4)\end{array}$ & All (4) & Yong et al., 2000 \\
\hline Sichuan & Diarrhea patients & $2^{a}$ & Case reports & & & Chen, 2001 \\
\hline Henan & Inpatients & $18^{a}$ & Genotypes identified & $\begin{array}{l}A(12) \\
B(6)\end{array}$ & $\mathrm{Al}(8) ; \mathrm{All}(4)$ & Wang et al., 2011 \\
\hline Hebei: Chengde & Resident & 216 & $3(1.39 \%)$ & $A(3)$ & All (3) & Chen et al., 2000 \\
\hline Anhui: Huainan & School pupils & 1,332 & $81(6.08 \%)$ & & & Fu et al., 2004 \\
\hline Hainan: Haikou & Elementary school students & 535 & $8(1.50 \%)$ & & & Gan et al., 2006 \\
\hline Henan: Kaifeng & Patients & 6,093 & $10(0.16 \%)$ & & & Wang et al., 2009 \\
\hline Henan: Zhengzhou & Patients & 4,836 & $11(0.23 \%)$ & & & Sun et al., 2010 \\
\hline Henan: Zhengzhou & Children patients & 1,996 & $12(0.60 \%)$ & & & Xu et al., 2011 \\
\hline Anhui: Fuyang & HIV positive patients & 302 & $4(1.32 \%)$ & & & Tian et al., 2012 \\
\hline Anhui: Fuyang & HIV negative individuals & 303 & $2(0.66 \%)$ & & & Tian et al., 2012 \\
\hline Shanghai & $\begin{array}{l}\text { Children with various congenital } \\
\text { or inherited diseases }\end{array}$ & $74^{\mathrm{b}}$ & 7 (9.46\%) & $A(6)$ & All (6) & Wang L. et al., 2013 \\
\hline Shanghai & $\begin{array}{l}\text { Children attending the } \\
\text { endocrinology }\end{array}$ & 283 & $4(1.41 \%)$ & $\begin{array}{l}A(2) \\
B(2)\end{array}$ & All (2) & Wang L. et al., 2013 \\
\hline Shanghai & $\begin{array}{l}\text { children attending general } \\
\text { surgeries }\end{array}$ & 216 & 0 & & & Wang L. et al., 2013 \\
\hline Shanghai & Children & 3,472 & $25(0.72 \%)$ & $\begin{array}{l}\text { A (17) } \\
B(9)\end{array}$ & All (17) & Wang L. et al., 2013 \\
\hline Shanghai & Diarrhea outpatients & 252 & 17 (6.75\%) & $\begin{array}{l}B(1) \\
C(16)\end{array}$ & & Liu H. et al., 2014 \\
\hline Hubei: Chibi & Kindergarten children & 20 & $1(5.00 \%)$ & & & Yuan et al., 2015 \\
\hline Shanghai & Diarrhea patients & 95 & $1(1.05 \%)$ & $B(1)$ & & Liu H. et al., 2015 \\
\hline Tibet: Lhasa & Resident & 1,015 & $4(0.39 \%)$ & & & Liu et al., 2016 \\
\hline Guangdong: Shenzhen & Diarrhea children & 126 & 0 & & & Shen et al., 2016 \\
\hline Guangdong: Shenzhen & Diarrhea adults patients & 286 & 0 & & & Shen et al., 2016 \\
\hline Guangdong: Shenzhen & Diarrhea patients <18 & 126 & 0 & & & Shen et al., 2016 \\
\hline Yunnan: Kunming & Diarrhea children & 850 & 0 & & & Zhang S. X. et al., 2016 \\
\hline Yunnan: Kunming & Diarrhea children & 170 & 0 & & & Zhang S. X. et al., 2016 \\
\hline Wuhan & Diarrhea children & 500 & $7(1.40 \%)$ & $A(7)$ & All (7) & Wang T. et al., 2017 \\
\hline Total & & 23,098 & $197(0.85 \%)$ & $\begin{array}{l}\text { A (51); B } \\
(23) ; C(16)\end{array}$ & Al (8); All (43) & \\
\hline
\end{tabular}

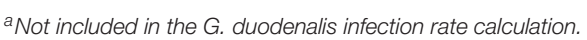

${ }^{b}$ Specimens from a cryptosporidiosis outbreak.

2006). The average infection rate in cattle (including dairy cattle, beef cattle, and yaks) is $5.43 \%(693 / 12,753)$, with the highest rate observed in Shaanxi Province (18.87\%, 70/371). However, use of different detection methods may contribute to the observed differences in prevalence.

There is a significant association between G. duodenalis infection and age in cattle. Most studies have reported that G. duodenalis infection rates are inversely associated with animal age in China (Liu et al., 2012; Huang et al., 2014; Wang et al., 2014b; Liu G. et al., 2015; Qi et al., 2015a; Li F. et al., 2016; Zhang et al., 2016b; Wang G. et al., 2017), except for a recent study from Xinjiang, which identified a higher prevalence in post-weaned calves (16.6\%) compared with pre-weaned calves (9.7\%; Qi et al., 2016b).

Cattle are dominantly infected with livestock-specific G. duodenalis assemblage E strains (Liu G. et al., 2015; Qi et al., 2015a; Li F. et al., 2016; Wang G. et al., 2017), with only a few reports of infection caused by assemblage $\mathrm{A}$ and/or $\mathrm{B}$ strains (Liu et al., 2012; Huang et al., 2014; Wang et al., 2014b; Zhang et al., 2016a). Moreover, sub-assemblages AI, AII, and AIII were identified by most studies conducted in China, with sub-assemblage AI found to be dominant (Wang et al., 2014b; Qi et al., 2016b; Wang X. T. et al., 2016). Mixed infections also appear to be common in cattle, especially those involving isolates 
TABLE 2 | Giardia duodenalis infection rates and genotypes in non-human primates in China.

\begin{tabular}{|c|c|c|c|c|c|c|}
\hline Locations & Specimens & Positive (\%) & Host species (no.) & $\begin{array}{l}\text { Assemblage } \\
\text { (no.) }\end{array}$ & $\begin{array}{l}\text { Subassemblage } \\
\text { (no.) }\end{array}$ & References \\
\hline Henan & 74 & $1(1.35 \%)$ & Rhesus macaque (1) & & & Zhao et al., 2011 \\
\hline Guangxi & 232 & 0 & & & & Zhao et al., 2011 \\
\hline Sichuan & 40 & 0 & & & & Zhao et al., 2011 \\
\hline \multirow[t]{2}{*}{ Guizhou } & 411 & $35(8.52 \%)$ & Rhesus macaque (10) & $A(10)$ & All (10) & Ye et al., 2012 \\
\hline & & & Rhesus macaque (24) & $B(24)$ & & \\
\hline Guangxi & 784 & $4(0.51 \%)$ & Rhesus macaque / Cynomolgus monkey & & & Li J. et al., 2013 \\
\hline \multirow[t]{2}{*}{ Guangxi } & 205 & $5(2.44 \%)$ & Rhesus macaque (2) & $A(2)$ & All (2) & Ye et al., 2014 \\
\hline & & & Rhesus macaque (3) & $\mathrm{B}(3)$ & & \\
\hline \multirow[t]{2}{*}{ Beijing } & 72 & $16(22.22 \%)$ & Cynomolgus monkey (1) & $A(1)$ & Alll (1) & Karim et al., 2014, 2015 \\
\hline & & & $\begin{array}{l}\text { Ring-tailed lemur (6); Squirrel monkey (5); } \\
\text { Golden monkey (3); Cynomolgus monkey (1) }\end{array}$ & $\mathrm{B}(15)$ & BIV (15) & \\
\hline Hebei & 89 & $10(11.24 \%)$ & $\begin{array}{l}\text { Ring-tailed lemur (5); Rhesus macaque (4); } \\
\text { Mona monkey (1) }\end{array}$ & $\mathrm{B}(10)$ & BIV (10) & Karim et al., 2014, 2015 \\
\hline Henan & 518 & $20(3.86 \%)$ & $\begin{array}{l}\text { Rhesus macaque (14); Japanese macaque (3); } \\
\text { Olive baboon (2); Assam macaque (1) }\end{array}$ & $\mathrm{B}(20)$ & BIV (20) & Karim et al., 2014, 2015 \\
\hline Shanxi & 66 & $9(13.64 \%)$ & $\begin{array}{l}\text { Rhesus macaque (5); Yellow baboon (2); } \\
\text { Northern white-cheeked gibbon (2) }\end{array}$ & $\mathrm{B}(9)$ & $\mathrm{BIV}(9)$ & Karim et al., 2014, 2015 \\
\hline Shaanxi & 197 & $4(2.03 \%)$ & Rhesus macaque (3); Saimiri sciureus (1) & $E(4)$ & & Du et al., 2015 \\
\hline \multirow[t]{2}{*}{ Shanghai } & 128 & 19 (14.84\%) & Green monkey (1) & $A(1)$ & $\mathrm{Al}(1)$ & Karim et al., 2014, 2015 \\
\hline & & & $\begin{array}{l}\text { Ring-tailed lemur (10); Golden monkey (2); } \\
\text { Squirrel monkey (2); Cynomolgus monkey (2) } \\
\text { King colobus (1); Mandrill (1) }\end{array}$ & $\mathrm{B}(18)$ & BIV (18) & \\
\hline Hubei & 66 & $5(7.58 \%)$ & Pig-tailed macaque (4); Hamadryas baboon (1) & $\mathrm{B}(5)$ & BIV (5) & Karim et al., 2014, 2015 \\
\hline \multirow[t]{2}{*}{ Hunan } & 75 & $33(44.00 \%)$ & Ring-tailed lemur (2) & $A(2)$ & Al (1); All (1) & Karim et al., 2014, 2015 \\
\hline & & & $\begin{array}{l}\text { Pig-tailed macaque (8); Bornean orangutan (5); } \\
\text { Hussar monkey (5); Ring-tailed lemur (3); } \\
\text { Squirrel monkey (3); Cynomolgus monkey (3); } \\
\text { Green monkey (2); Roloway monkey (1); } \\
\text { Francois' leaf monkey (1) }\end{array}$ & $\mathrm{B}(31)$ & BIV (31) & \\
\hline Guangdong & 57 & $1(1.75 \%)$ & Cynomolgus monkey (1) & $B(1)$ & $\mathrm{BIV}(1)$ & Karim et al., 2014, 2015 \\
\hline Guangxi & 363 & $9(2.48 \%)$ & Rhesus macaque (8); White-headed (1) & $\mathrm{B}(9)$ & BIV (9) & Karim et al., 2014, 2015 \\
\hline Sichuan & 304 & 0 & & & & Karim et al., 2014, 2015 \\
\hline Yunnan & 144 & 0 & & & & Karim et al., 2014, 2015 \\
\hline Henan & 2 & $1(50.00 \%)$ & Nomascus leucogenys (1) & $B(1)$ & & Li J. et al., 2015 \\
\hline Total & 3,827 & $172(4.49 \%)$ & & $\begin{array}{l}\text { A (16); B } \\
\text { (146); E (4) }\end{array}$ & $\begin{array}{l}\text { AI (2); AII (13); } \\
\text { AIII (1); BIV (118) }\end{array}$ & \\
\hline
\end{tabular}

belonging to assemblages A and E (Wang et al., 2014b; Liu G. et al., 2015).

Several studies using MLG have suggested the possibility of geographical distribution differentiation among assemblage $\mathrm{E}$ isolates in cattle (Wang et al., 2014b; Qi et al., 2016b; Wang X. T. et al., 2016; Zhang et al., 2016a). A MLG subtype AII isolate identical to human-derived isolates from Italy, Sweden, and China was identified in dairy cattle from Henan Province, raising the possibility of it being an important zoonotic multilocus genotype (Wang et al., 2014b).

Limited information is available on the prevalence and assemblage distribution of $G$. duodenalis in yaks, despite confirmed cases of infection in Qinghai, Gansu, Sichuan, and Henan Provinces, as well as in Tibet (Ma et al., 2014; Qi et al., 2015a; Song et al., 2016; Wang et al., 2016a,b; Wang G. et al.,
2017). Thus far, only assemblage $\mathrm{E}$ isolates have been identified in yaks in China.

\section{G. DUODENALIS IN SHEEP AND GOATS}

Reports of G. duodenalis infections in sheep and goats in recent years have presented variable results (Table 4). The average infection rate in sheep and goats is $6.07 \%(418 / 6,890)$, with the highest infection rate recorded in goats from Chongqing city $(27.78 \%, 5 / 18)$. Except for one study that identified two assemblage B-type isolates in sheep in Heilongjiang (Zhang et al., 2012c), all reports of $G$. duodenalis infections in sheep and goats in China were caused by assemblage $\mathrm{E}$ and A strains, with assemblage $\mathrm{E}$ being significantly dominant (Gu et al., 2014; Peng et al., 2016; Wang H. et al., 2016). 
TABLE 3 | Giardia duodenalis infection rates and genotypes in cattle in China.

\begin{tabular}{|c|c|c|c|c|c|c|}
\hline Animals & Locations & Specimens & Positive (\%) & Assemblage (no.) & Subassemblage (no.) & References \\
\hline Dairy cattle & Guangdong & $1^{a}$ & Case report & $E(1)$ & & Xiao et al., 2006 \\
\hline \multirow[t]{2}{*}{ Dairy cattle } & Heilongjiang & $26^{a}$ & Genotypes identified & $\mathrm{B}(10)$ & & Liu A. et al., 2014 \\
\hline & & & & $E(16)$ & & \\
\hline Dairy cattle & Jilin & 249 & $19(7.63 \%)$ & $E(19)$ & & Zhang J. et al., 2012 \\
\hline \multirow[t]{2}{*}{ Dairy cattle } & Heilongjiang & 52 & $4(7.69 \%)$ & $A(1)$ & $\mathrm{Al}(1)$ & Zhang J. et al., 2012 \\
\hline & & & & $E(3)$ & & \\
\hline \multirow[t]{3}{*}{ Dairy cattle } & Heilongjiang & 814 & $42(5.16 \%)$ & B (18) & $\begin{array}{l}\mathrm{BI}(6) ; \mathrm{BII}(1) ; \mathrm{BIII}(2) ; \mathrm{BIV}(2) ; \mathrm{BV}(1) ; \\
\mathrm{BVI}(1) ; \mathrm{BVII}(1) ; \mathrm{BVIII}(3) ; \operatorname{BIX}(1)\end{array}$ & Liu et al., 2012 \\
\hline & & & & $E(24)$ & & \\
\hline & & & & $\mathrm{A} / \mathrm{E}(1)$ & & \\
\hline Dairy cattle & Heilongjiang & 52 & $8(15.38 \%)$ & $E(8)$ & & Liu G. et al., 2015 \\
\hline \multirow[t]{2}{*}{ Dairy cattle } & Jilin & 377 & 25 (6.63\%) & $A(1)$ & $\mathrm{Al}(1)$ & Liu G. et al., 2015 \\
\hline & & & & $E(24)$ & & \\
\hline \multirow[t]{2}{*}{ Dairy cattle } & Liaoning & 226 & 19 (8.41\%) & $E(18)$ & & Liu G. et al., 2015 \\
\hline & & & & $\mathrm{A} / \mathrm{E}(1)$ & & \\
\hline Dairy cattle & Beijing & 822 & $14(1.70 \%)$ & $E(14)$ & & Li F. et al., 2016 \\
\hline \multirow[t]{3}{*}{ Dairy cattle } & Henan & 1,777 & $128(7.20 \%)$ & $A(21)$ & Al (4); All (3); AllI (1) & Wang et al., 2014b \\
\hline & & & & $E(58)$ & & \\
\hline & & & & $\mathrm{A} / \mathrm{E}(2)$ & & \\
\hline Dairy cattle & Henan & 622 & $21(3.38 \%)$ & & & Wang et al., 2014a \\
\hline Dairy cattle & Henan & 507 & $48(9.47 \%)$ & $E(48)$ & & Wang C. et al., 2016 \\
\hline Dairy cattle & Henan & 622 & $21(3.38 \%)$ & $E(21)$ & & Zhao et al., 2016 \\
\hline \multirow[t]{2}{*}{ Dairy cattle } & Xinjiang & 514 & $69(13.42 \%)$ & $A(5)$ & Al (3); All (2) & Qi et al., 2016b \\
\hline & & & & $E(64)$ & & \\
\hline Dairy cattle & Gansu & 1,224 & $32(2.61 \%)$ & $E(32)$ & & Zhang et al., 2016a \\
\hline \multirow[t]{2}{*}{ Dairy cattle } & Ningxia & 1,366 & $29(2.12 \%)$ & $\mathrm{B}(4)$ & $\mathrm{BI}(1) ; \mathrm{BII}(3)$ & Huang et al., 2014 \\
\hline & & & & $E(25)$ & & \\
\hline \multirow[t]{2}{*}{ Dairy cattle } & Ningxia & 1,614 & 74 (4.58\%) & $A(1)$ & & Zhang et al., 2016a \\
\hline & & & & $E(73)$ & & \\
\hline Cattle & Qinghai & 47 & $3(6.38 \%)$ & & & Ma et al., 2014 \\
\hline \multirow[t]{2}{*}{ Beef/dairy cattle } & Shaanxi & 371 & 70 (18.87\%) & $A(8)$ & $\mathrm{Al}(8)$ & Wang X. T. et al., 2016 \\
\hline & & & & $E(62)$ & & \\
\hline Yak & Qinghai & 57 & 7 (12.28\%) & & & Ma et al., 2014 \\
\hline Yak & Henan & 34 & $2(5.88 \%)$ & $E(2)$ & & Qi et al., 2015a \\
\hline Yak & Gansu & 117 & $4(3.42 \%)$ & $E(4)$ & & Qi et al., 2015a \\
\hline Yak & Sichuan & 146 & $4(2.74 \%)$ & $E(4)$ & & Qi et al., 2015a \\
\hline Yak & Tibet & 96 & $1(1.04 \%)$ & $E(1)$ & & Qi et al., 2015a \\
\hline Yak & Qinghai & 152 & 5 (3.29\%) & $E(5)$ & & Qi et al., 2015a \\
\hline Yak & Qinghai & 93 & $8(8.60 \%)$ & $E(9)$ & & Wang et al., 2016a \\
\hline Yak & Qinghai & 297 & $22(7.41 \%)$ & $E(22)$ & & Wang et al., 2016b \\
\hline Yak & Gansu & 208 & $4(1.92 \%)$ & $E(4)$ & & Song et al., 2016 \\
\hline Yak & Qinghai & 297 & 10 (3.37\%) & $E(10)$ & & Wang G. et al., 2017 \\
\hline Total & & 12,753 & $693(5.43 \%)$ & $\begin{array}{l}\text { E (571); A (37); B } \\
\text { (32); A/E (4) }\end{array}$ & $\begin{array}{l}\text { AI (17); AII (5); AIII (1); BI (7); BII } \\
\text { (4); BIII (2); BIV (2); BV (1); BVI (1); } \\
\text { BVII (1); BVIII (3); BIX (1) }\end{array}$ & \\
\hline
\end{tabular}

a Not included in the G. duodenalis infection rate calculation.

Mixed infections of assemblage A and E strains in sheep are commonly reported (Ye et al., 2015; Wang H. et al., 2016), while sub-assemblage AI was generally the dominant subgenotype (Zhang et al., 2012c; Ma et al., 2014; Peng et al.,
2016; Wang H. et al., 2016). A recent study from Henan Province using MLG yielded one new AI sub-assemblage with zoonotic potential, and six assemblage E MLGs (Wang $\mathrm{H}$. et al., 2016). 
TABLE 4 | Giardia duodenalis infection rates and genotypes in sheep and goats in China.

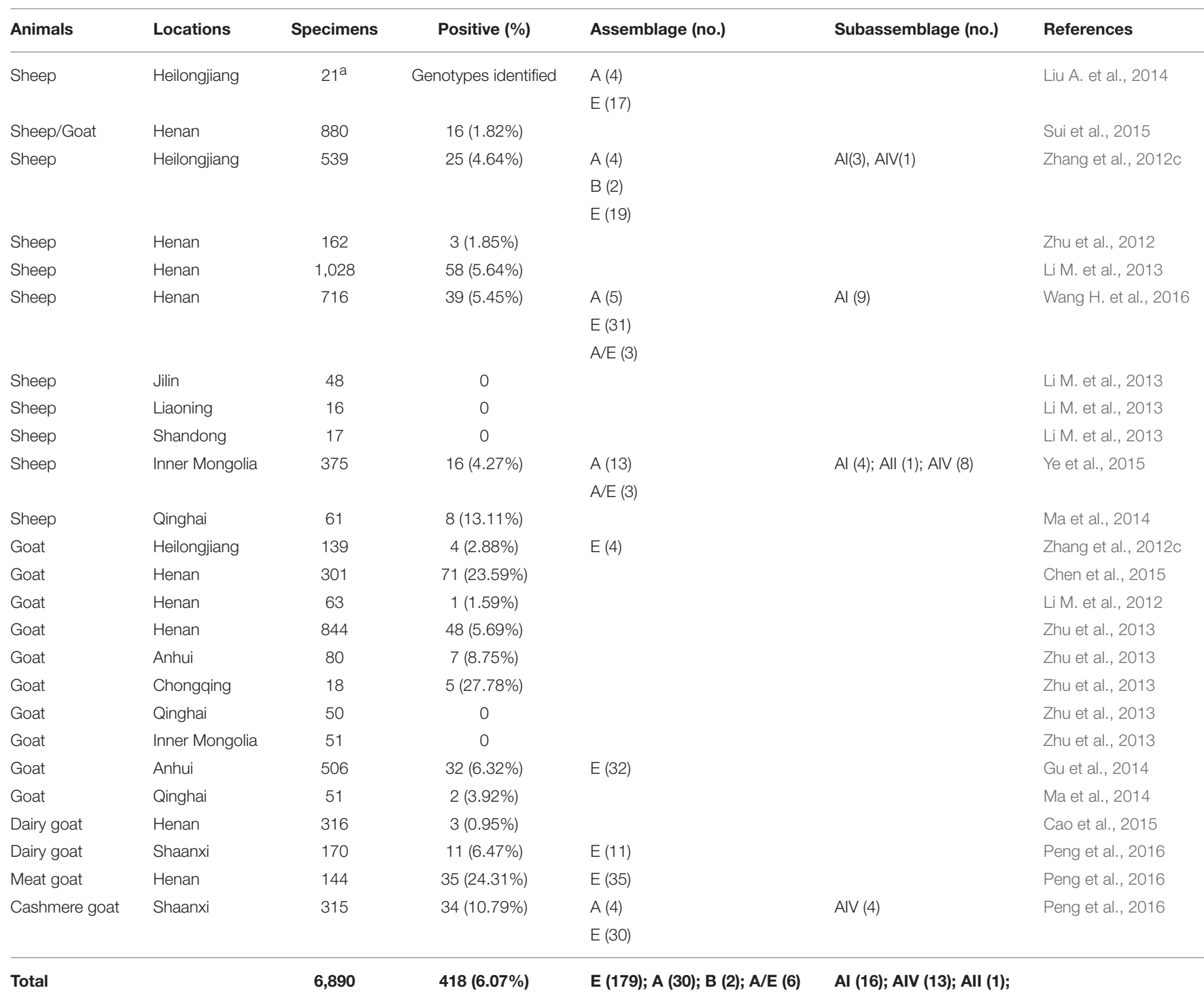

aNot included in the $\mathrm{G}$. duodenalis infection rate calculation.

\section{G. DUODENALIS IN DOGS AND CATS}

In recent decades, a large number of cases of $G$. duodenalis infection in dogs, and some in cats, have been documented in different regions of China (Table 5). The first report of G. duodenalis infection in dogs occurred in 2000 in Jilin Province (He et al., 2000). The average infection rate in dogs is $13.64 \%$ $(757 / 5,549)$, with the highest rate in Shanghai City $(26.19 \%$, 127/485) (Xu et al., 2016), whereas the average rate in cats is $10.19 \%(32 / 314)$, with the highest rate of infection also observed in Shanghai (13.13\%, 21/160) (Xu et al., 2016).

Scant information on the epidemiology or molecular characteristics of $G$. duodenalis in dogs and cats in China is currently available. G. duodenalis assemblages A, C, and D have been identified as the most common genotypes in dogs, with $\mathrm{A}$ and $\mathrm{F}$ most prevalent in cats. Occasionally, assemblage $\mathrm{B}$ and $\mathrm{E}$ isolates have been reported (e.g., in two studies on dogs; $\mathrm{Gu}$ et al., 2015; Li W. et al., 2015), while assemblage B, C, and D isolates have been reported in cats (Zheng et al., 2015; Xu et al., 2016).

In general, sub-assemblage AI appears to be the dominant sub-genotype amongst isolates derived from dogs and cats in China (Li et al., 2012b; Li W. et al., 2013; Zheng et al., 2014, 2015), which agrees with findings from the limited number of reports from dogs and cats in Europe, USA, Brazil, Australia, and Japan (Vasilopulos et al., 2007; Volotão et al., 2007; Sprong et al., 2009; Feng and Xiao, 2011). However, one study from Shanghai showed that amongst 25 assemblage A sequences obtained from dog and cat specimens, 23 canine sequences and one feline sequence were identified as subtype AII (Xu et al., 2016). 
TABLE 5 | Giardia duodenalis infection rates and genotypes in dogs and cats in China.

\begin{tabular}{|c|c|c|c|c|c|c|}
\hline Animals & Locations & Specimens & Positive (\%) & Assemblage (no.) & Subassemblage (no.) & References \\
\hline Dog & Jilin & $1^{a}$ & Case report & & & He et al., 2000 \\
\hline Dog & Jilin & $1^{a}$ & Case report & & & He et al., 2002 \\
\hline Dog & Beijing & $2^{a}$ & Case reports & & & Gao et al., 2009 \\
\hline Dog & Guangdong & $1^{\mathrm{a}}$ & Case report & $A(1)$ & & Zhu et al., 2011 \\
\hline Dog & Guangdong & $2^{a}$ & Case reports & $\begin{array}{l}A(1) \\
D(1)\end{array}$ & $\mathrm{Al}(1)$ & Zhang et al., 2011 \\
\hline Dog & Guangdong & $1^{\mathrm{a}}$ & Case report & $\mathrm{D}(1)$ & & Li et al., 2011 \\
\hline Dog & Guangdong & $1^{a}$ & Case report & $D(1)$ & & Li et al., 2012a \\
\hline Dog & Shaanxi & $56^{a}$ & Case statistics & & & Quan et al., 2016 \\
\hline Dog & Jinlin & 242 & $61(25.21 \%)$ & & & He et al., 2001 \\
\hline Dog & Henan & 404 & $15(3.71 \%)$ & & & Qi et al., 2010a \\
\hline Dog & Henan & 531 & $72(13.56 \%)$ & & & Qi et al., 2011 \\
\hline Dog & Sichuan & 146 & 46 (31.51\%) & & & Hu et al., 2011 \\
\hline Dog & Beijing & 910 & 109 (11.98\%) & & & Bi et al., 2011 \\
\hline Dog & Shaanxi & 120 & $11(9.17 \%)$ & & & Wang et al., 2015 \\
\hline Dog & Henan & 358 & $71(19.83 \%)$ & & & Dong et al., 2015 \\
\hline \multirow[t]{2}{*}{ Dog } & Guangdong & 209 & 23 (11.00\%) & $A(5)$ & $\mathrm{Al}(5)$ & Li et al., 2012b \\
\hline & & & & $\mathrm{D}(23)$ & & \\
\hline \multirow[t]{2}{*}{ Dog } & Liaoning & 205 & 27 (13.17\%) & $A(25)$ & $\mathrm{Al}(25)$ & Li W. et al., 2013 \\
\hline & & & & C (2) & & \\
\hline \multirow[t]{6}{*}{ Dog } & Guangdong & 216 & $21(9.72 \%)$ & $A(7)$ & $\mathrm{Al}(7)$ & Zheng et al., 2014 \\
\hline & & & & $\mathrm{C}(2)$ & & \\
\hline & & & & $\mathrm{D}(1)$ & & \\
\hline & & & & $\mathrm{A} / \mathrm{C}(2)$ & & \\
\hline & & & & A/D (7); & & \\
\hline & & & & C/D (2) & & \\
\hline \multirow[t]{2}{*}{ Dog } & Heilongjiang & 267 & $12(4.49 \%)$ & $C(7)$ & & Li W. et al., 2015 \\
\hline & & & & $E(5)$ & & \\
\hline \multirow[t]{2}{*}{ Dog } & Henan & 940 & 134 (14.26\%) & C (37) & & Qi et al., 2016a \\
\hline & & & & $\mathrm{D}(44)$ & & \\
\hline \multirow[t]{7}{*}{ Dog } & Shanghai & 485 & 127 (26.19\%) & A (23) & All (23) & Xu et al., 2016 \\
\hline & & & & $\mathrm{B}(1)$ & & \\
\hline & & & & C (26) & & \\
\hline & & & & $\mathrm{D}(58)$ & & \\
\hline & & & & $\mathrm{A} / \mathrm{C}(2)$ & & \\
\hline & & & & $\mathrm{A} / \mathrm{D}(1)$ & & \\
\hline & & & & C/D (10) & & \\
\hline Dog & Qinghai & 31 & $2(6.45 \%)$ & & & Ma et al., 2014 \\
\hline Dog & Qinghai & 10 & $1(10.00 \%)$ & $A(1)$ & & Wang G. et al., 2013 \\
\hline Dog & Taiwan & 42 & $4(9.52 \%)$ & & & Liang et al., 2012 \\
\hline \multirow[t]{2}{*}{ Dog } & Taiwan & 118 & $11(9.32 \%)$ & $\mathrm{C}(7)$ & & Tseng et al., 2014 \\
\hline & & & & $\mathrm{D}(4)$ & & \\
\hline \multirow[t]{2}{*}{ Dog } & Anhui & 215 & $10(4.65 \%)$ & $B(6)$ & & Gu et al., 2015 \\
\hline & & & & $\mathrm{D}(4)$ & & \\
\hline Dog & Zhejiang & 100 & 0 & & & Gu et al., 2015 \\
\hline Subtotal & & 5,549 & 757 (13.64\%) & $\begin{array}{l}\text { D (137); C (81); A (63); B (7); E (5); } \\
\text { C/D (12); A/D (8); A/C (4) }\end{array}$ & Al (38); All (23) & \\
\hline Cat & Hebei & $1^{a}$ & Case report & & & Cui et al., 2010 \\
\hline Cat & Guangdong & $1^{a}$ & Case report & $F(1)$ & & Zheng et al., 2013 \\
\hline
\end{tabular}




\begin{tabular}{|c|c|c|c|c|c|c|}
\hline Animals & Locations & Specimens & Positive (\%) & Assemblage (no.) & Subassemblage (no.) & References \\
\hline \multirow[t]{3}{*}{ Cat } & Guangdong & 102 & $10(9.80 \%)$ & $A(8)$ & $\mathrm{Al}(8)$ & Zheng et al., 2015 \\
\hline & & & & $F(1)$ & & \\
\hline & & & & $\mathrm{A} / \mathrm{C}(1)$ & & \\
\hline \multirow[t]{5}{*}{ Cat } & Shanghai & 160 & 21 (13.13\%) & $A(2)$ & $\mathrm{Al}(1) ; \mathrm{All}(1)$ & Xu et al., 2016 \\
\hline & & & & B (6); & & \\
\hline & & & & $C(2)$ & & \\
\hline & & & & $\mathrm{D}(1)$ & & \\
\hline & & & & $F(7)$ & & \\
\hline Cat & Heilongjiang & 52 & $1(1.92 \%)$ & $F(1)$ & & Li W. et al., 2015 \\
\hline Subtotal & & 314 & $32(10.19 \%)$ & $\begin{array}{l}\text { A (10); F (10); B (6); C (2); D (1); } \\
\text { A/C (1) }\end{array}$ & Al (9); All (1) & \\
\hline
\end{tabular}

${ }^{a}$ Not included in the $\mathrm{G}$. duodenalis infection rate calculation.

\section{G. DUODENALIS IN PIGS}

G. duodenalis infections in pigs have been reported in Australia, Africa, Asia, Europe, and North America (Feng and Xiao, 2011). However, there are limited reports on the prevalence and genotypes of this organism in pigs in China, except in Sichuan Province, where the average infection rate was $3.51 \%$ (24/683, Table 6). Although assemblage E was the predominant genotype amongst these isolates from China, assemblage $\mathrm{A}$ is also frequently identified (Li W. et al., 2016; Li J. et al., 2017). In contrast, isolates belonging to assemblages $\mathrm{A}-\mathrm{F}$ have been found in domestic pigs in other countries, with assemblage $\mathrm{B}$ and $\mathrm{E}$ isolates found in Canada (Budu-Amoako et al., 2012), assemblage $\mathrm{C}$ and $\mathrm{F}$ isolates in the UK (Minetti et al., 2014), assemblage A, $\mathrm{D}$, and $\mathrm{E}$ isolates in Denmark (Petersen et al., 2015), and isolates belonging to assemblages $\mathrm{A}, \mathrm{E}$, and $\mathrm{F}$ identified in Australia (Armson et al., 2009). Thus far, the majority of the assemblage A strains from pigs in China belong to sub-assemblage AI ( $\mathrm{Li} \mathrm{W}$. et al., 2016, 2017).

\section{G. DUODENALIS IN RABBITS}

G. duodenalis infections occur in rabbits in China at an average rate of $6.86 \%(271 / 3,746)$, and have mainly been documented in Henan and Heilongjiang Provinces (Table 6). Although assemblage E isolates are occasionally found (Qi et al., 2015b), assemblage B strains appear dominant in rabbits in China (Zhang et al., 2012b; Liu A. et al., 2014; Qi et al., 2015b), which agrees with reports from Europe (Pantchev et al., 2014) and the USA (Sulaiman et al., 2003).

\section{G. DUODENALIS IN RODENTS}

G. duodenalis infections have been reported in rodents in Norway (Robertson et al., 2007), Poland (Bajer, 2008), Latin America (Bueno et al., 2016), Europe (Pantchev et al., 2014), and Sweden (Lebbad et al., 2010). Currently, G. duodenalis infections in rodents in China have only been reported in Henan Province, where the average infection rate was $20.09 \%$ (213/1,060; Table 6).
According to the limited number of genotyping studies on G. duodenalis in rodents in China, only assemblage A and B strains, which have zoonotic potential, and host-adapted assemblage $\mathrm{G}$ isolates have been identified (Qi et al., 2015c; Zhao Z. et al., 2015).

\section{G. DUODENALIS IN OTHER MAMMALS}

G. duodenalis infections have also been reported in beavers, Chinese leopards, Siberian tigers, golden takins, raccoon dogs, horses, deer, and donkeys (Table 7). Some of these infections have high prevalence rates, such as in donkeys in Shandong Province (18.27\%, 19/104) (Zhang et al., 2017), raccoon dogs in Liaoning Province (15.28\%, 11/72) (Zhang et al., 2016b), golden takins in Shaanxi Province $(8.90 \%, 17 / 191)$ (Zhao G. H. et al., 2015), and Pika $(9.09 \%, 1 / 11)$ and donkeys $(7.69 \%, 1 / 13)$ in Qinghai Province (Ma et al., 2014).

Certain G. duodenalis assemblages have been associated with host adaptation in specific animals, such as, assemblages $C$ and $\mathrm{D}$ in raccoon dogs (Zhang et al., 2016b), assemblage $\mathrm{E}$ in golden takins (Zhao G. H. et al., 2015) and deer (unpublished data), and assemblage $\mathrm{F}$ in a Chinese leopard and Siberian tigers (Li J. et al., 2015). Zoonotic G. duodenalis isolates belonging to assemblages A and B were also identified in beavers (Li J. et al., 2015), golden takins (Zhao G. H. et al., 2015), and horses (Qi et al., 2015d). The number of zoonotic isolates found in wild animals is quite limited, an observation supported by a large survey of G. duodenalis in wild mammals from Croatia that revealed a low prevalence and limited zoonotic potential for the parasite (Beck et al., 2011). This suggests that wild animals are probably not a major reservoir for human infections.

\section{G. DUODENALIS IN WASTEWATER}

Cases of giardiasis associated with polluted recreational and potable waters have been documented for more than a century worldwide (Guy et al., 2003; Karanis et al., 2007; Moss, 2016). Although there have been no G. duodenalis outbreaks documented in China, a high prevalence of oocysts was identified 
TABLE 6 | Giardia duodenalis infection rates and genotypes in pigs, rabbits, and rodents in China.

\begin{tabular}{|c|c|c|c|c|c|c|}
\hline Animals & Locations & Specimens & Positive (\%) & Assemblage (no.) & Subassemblage (no.) & References \\
\hline \multirow[t]{2}{*}{ Wild boars } & Sichuan & 308 & $11(3.57 \%)$ & $A(1)$ & $\mathrm{Al}(1)$ & Li W. et al., 2016 \\
\hline & & & & $E(10)$ & & \\
\hline Pig & Sichuan & 18 & $2(11.11 \%)$ & $E(2)$ & & Li W. et al., 2016 \\
\hline \multirow[t]{2}{*}{ Wild boars } & Sichuan & 357 & $11(3.08 \%)$ & $A(2)$ & $\mathrm{Al}(2)$ & Li J. et al., 2017 \\
\hline & & & & $E(9)$ & & \\
\hline Subtotal & & 683 & $24(3.51 \%)$ & E (21); A (3) & $\mathrm{Al}(3)$ & \\
\hline Rabbits & Heilongjiang & $14^{\mathrm{a}}$ & Genotypes identified & $\mathrm{B}(14)$ & & Liu A. et al., 2014 \\
\hline Rabbits & Henan & 1,027 & 80 (7.79\%) & & & Xi et al., 2011b \\
\hline Rabbits & Henan & 1,081 & 57 (5.27\%) & & & Shi et al., 2010 \\
\hline Rabbits & Henan & 305 & 12 (3.93\%) & & & Xi et al., 2011a \\
\hline Rabbits & Heilongjiang & 378 & 28 (7.40\%) & $\mathrm{B}(28)$ & BI (18);BII (4); BIII (3); BIV (1); BV (1); BVI (1) & Zhang et al., 2012b \\
\hline \multirow[t]{3}{*}{ Rabbits } & Henan & 955 & $80(8.38 \%)$ & $B(26)$ & BIV (26) & Qi et al., 2015b \\
\hline & & & & $E(2)$ & & \\
\hline & & & & $\mathrm{B} / \mathrm{E}(4)$ & & \\
\hline Subtotal & & 3,746 & $257(6.86 \%)$ & B (68); E (2); B/E (4) & BI (18); BII (4); BIII (3); BIV (27); BV (1); BVI (1) & \\
\hline \multirow[t]{2}{*}{ Rodent } & Henan & 140 & 38 (27.14\%) & $A(5)$ & $\mathrm{Al}(5)$ & Qi et al., 2015c \\
\hline & & & & $\mathrm{B}(33)$ & BIV (31) & \\
\hline Rodent & Henan & 232 & $14(6.03 \%)$ & $\mathrm{G}(14)$ & & Zhao Z. et al., 2015 \\
\hline Rodent & Henan & 96 & $36(37.50 \%)$ & & & Lv et al., 2009b \\
\hline Rodent & Henan & 439 & $91(20.72 \%)$ & & & Qi et al., 2010b \\
\hline Rodent & Henan & 153 & 34 (22.22\%) & & & Lv et al., 2009a \\
\hline Subtotal & & 1,060 & $213(20.09 \%)$ & B (33); G (14); A (5) & Al (5); BIV(31) & \\
\hline
\end{tabular}

${ }^{a}$ Not included in the $\mathrm{G}$. duodenalis infection rate calculation.

amongst samples from numerous municipal and domestic raw water sources in Shanghai (Zhang et al., 2010; Li N. et al., 2012), Guangzhou (Zhong et al., 2010; Sun et al., 2014), Wuhan (Li N. et al., 2012; Sun et al., 2014), Jiangsu (Sun et al., 2014), Harbin (Liu et al., 2011; Zhang et al., 2012a), Guiyang (Chen et al., 2009), Nanjing (Li N. et al., 2012), Qingdao (Li N. et al., 2012), Taiwan (Liang et al., 2012), and Qinghai (Ma et al., 2014), among others.

Assemblage A and B isolates, which have zoonotic potential, were identified in urban waste in China (Liu et al., 2011; Liang et al., 2012; Li N. et al., 2012), suggesting that this pathogen could be maintained and transmitted by water sources, with the attendant risk of disease outbreaks occurring. Similarly, zoonotic isolates were also identified in Iran (Mahmoudi et al., 2015), Australia (Nolan et al., 2013; Koehler et al., 2016), Malaysia (Lim et al., 2009a,b, and Portugal (Lobo et al., 2009), among others. Isolates belonging to other assemblages, such as assemblage $\mathrm{E}$, were also documented in wastewater in France (Bertrand and Schwartzbrod, 2007).

\section{CONCLUSIONS AND PERSPECTIVES}

In conclusion, G. duodenalis is widely distributed in humans and various other animals in China. Among the G. duodenalis assemblages, $\mathrm{A}$ and $\mathrm{B}$ are considered to have the broadest host specificities, and strains belonging to these assemblage types have zoonotic potential. Generally speaking, assemblage A isolates are more frequently found in humans, livestock, and companion animals, while assemblage $\mathrm{B}$ isolates are commonly isolated from humans, NHPs, and rabbits, with only a few reports of infections in sheep, goats, dogs, and cats in China. Cattle, sheep, goats, and pigs are predominantly infected with hostspecific assemblage $E$ isolates, while assemblage $C$ and $D$ isolates have been found in dogs, assemblage $\mathrm{F}$ is associated with cats, and rodents tend to be infected with assemblage $G$ isolates. Within assemblage A, humans and NHPs are more commonly infected with subgroup AII isolates, while in other animals, sub-assemblage AI is predominant.

Most molecular investigations of G. duodenalis in China have only examined one or two loci, which cannot provide sufficient information on the transmission profile of this pathogen. However, the availability of the whole genome sequence of $G$. duodenalis has enhanced population genetics-based studies, and multi-locus sequence typing (MLST) tools are increasingly being used for characterizing $G$. duodenalis infections in humans and animals. Access to these methods is especially important for gaining a better understanding of some host-adapted assemblages (e.g., C, D, E, and F) that are pathogenic in humans, and for assessing the zoonotic assemblages (A and B) with infective potential. Therefore, a comprehensive and systematic study based on MLST analysis should be carried out to allow a full assessment of the burden of giardiasis of animal origin in humans. 
TABLE 7 | Giardia duodenalis infection rates and genotypes in other mammals in China.

\begin{tabular}{|c|c|c|c|c|c|}
\hline Animals & Locations & Specimens & Positive (\%) & Assemblage (no.) & References \\
\hline Pika & Qinghai & 11 & 1 (9.09\%) & & Ma et al., 2014 \\
\hline Chinese leopard & Henan & 2 & $1(50.00 \%)$ & $F(1)$ & Li J. et al., 2015 \\
\hline Beaver & Henan & 1 & 1 (100.00\%) & $B(1)$ & Li J. et al., 2015 \\
\hline Siberian tiger & Henan & 6 & 2 (33.33\%) & $F(2)$ & Li J. et al., 2015 \\
\hline Golden takins & Shaanxi & 191 & 17 (8.90\%) & $\begin{array}{l}B(3) \\
E(14)\end{array}$ & Zhao G. H. et al., 2015 \\
\hline Grazing horses & Xinjiang & 262 & $4(1.50 \%)$ & $\begin{array}{l}\text { A (2) } \\
B(2)\end{array}$ & Qi et al., 2015d \\
\hline Raccoon dog & Jilin & 110 & 7 (6.36\%) & $\begin{array}{l}C(6) \\
C / D(1)\end{array}$ & Zhang et al., 2016b \\
\hline Raccoon dog & Heilongjiang & 40 & $3(7.50 \%)$ & C (3) & Zhang et al., 2016b \\
\hline Raccoon dog & Shandong & 29 & 0 & & Zhang et al., 2016b \\
\hline Raccoon dog & Hebei & 54 & $1(1.85 \%)$ & $C(1)$ & Zhang et al., 2016b \\
\hline Raccoon dog & Liaoning & 72 & $11(15.28 \%)$ & $\begin{array}{l}C(10) \\
C / D(1)\end{array}$ & Zhang et al., 2016b \\
\hline Donkey & Qinghai & 13 & $1(7.69 \%)$ & & Ma et al., 2014 \\
\hline Donkey & Jilin & 48 & 5 (10.42\%) & $\mathrm{B}(5)$ & Zhang et al., 2017 \\
\hline Donkey & Shandong & 104 & 19 (18.27\%) & $\mathrm{B}(19)$ & Zhang et al., 2017 \\
\hline Donkey & Liaoningz & 29 & $4(13.79 \%)$ & $B(4)$ & Zhang et al., 2017 \\
\hline Deer & Henan & 199 & $5(2.51 \%)$ & $E(5)$ & Unpublished \\
\hline Total & & 1,171 & $82(7.00 \%)$ & A (2); B (34); C (20); E (19); F (3); C/D (2) & \\
\hline
\end{tabular}

\section{AUTHOR CONTRIBUTIONS}

LZ conceived the idea for the review and revised the manuscript. $\mathrm{JL}$ and $\mathrm{HW}$ wrote the manuscript, and JL, HW, and RW reviewed and abstracted the data from each selected article.

\section{FUNDING}

This study was supported in part by the Key Program of the National Natural Science Foundation of China (31330079), the

\section{REFERENCES}

Adam, R. D., Dahlstrom, E. W., Martens, C. A., Bruno, D. P., Barbian, K. D., Ricklefs, S. M., et al. (2013). Genome sequencing of Giardia lamblia genotypes $\mathrm{A} 2$ and $\mathrm{B}$ isolates (DH and GS) and comparative analysis with the genomes of genotypes A1 and E (WB and Pig). Genome Biol. Evol. 5, 2498-2511. doi: 10.1093/gbe/evt197

Anuar, T. S., Azreen, S. N., Salleh, F. M., and Moktar, N. (2014). Molecular epidemiology of giardiasis among Orang Asli in Malaysia: application of the triosephosphate isomerase gene. BMC Infect Dis. 14:78. doi: 10.1186/1471-2334-14-78

Armson, A., Yang, R., Thompson, J., Johnson, J., Reid, S., and Ryan, U. M. (2009). Giardia genotypes in pigs in Western Australia: prevalence and association with diarrhea. Exp. Parasitol. 121, 381-383. doi: 10.1016/j.exppara.2009.01.008

Bajer, A. (2008). Between-year variation and spatial dynamics of Cryptosporidium spp. and Giardia spp. infections in naturally infected rodent populations. Parasitology. 135, 1629-1649. doi: 10.1017/S0031182008004952

Beck, R., Sprong, H., Lucinger, S., Pozio, E., and Cacciò, S. M. (2011). A large survey of Croatian wild mammals for Giardia duodenalis reveals a low prevalence
Natural Science Foundation of Henan Province (162300410129), the Key National Science and Technology Specific Projects (2012ZX10004220-001), and the National Natural Science Foundation of China (U1404327).

\section{ACKNOWLEDGMENTS}

We thank Tamsin Sheen, Ph. D, from Liwen Bianji, Edanz Editing China (www.liwenbianji.cn/ac), for editing the English text of a draft of this manuscript.

and limited zoonotic potential. Vector Borne Zoonotic Dis. 11, 1049-1055. doi: $10.1089 / \mathrm{vbz} .2010 .0113$

Bertrand, I., and Schwartzbrod, J. (2007). Detection and genotyping of Giardia duodenalis in wastewater: relation between assemblages and fecal contamination origin. Water Res. 41, 3675-3682. doi: 10.1016/j.watres.2007.02.043

Bi, T., Zhang, J., Wen, R., Han, J., Fu, Q., Wang, X., et al. (2011). Prevalence of experimental beagles with Giardia infections. Lab. Anim. Sci. 28, 78-80 (in Chinese). doi: 10.3969/j.issn.1006-6179.2011.02.022

Budu-Amoako, E., Greenwood, S. J., Dixon, B. R., Barkema, H. W., Hurnik, D., Estey, C., et al. (2012). Occurrence of Giardia and Cryptosporidium in pigs on Prince Edward Island, Canada. Vet Parasitol. 184, 18-24. doi: 10.1016/j.vetpar.2011.07.047

Bueno, I., Smith, K. M., Sampedro, F., Machalaba, C. C., Karesh, W. B., and Travis, D. A. (2016). Risk prioritization tool to identify the public health risks of wildlife trade: the case of rodents from Latin America. Zoonoses Public Health. 63, 281-293. doi: 10.1111/zph.12228

Cacciò, S. M., and Ryan, U. (2008). Molecular epidemiology of giardiasis. Mol. Biochem. Parasitol. 160, 75-80. doi: 10.1016/j.molbiopara.2008.04.006 
Cacciò, S. M., Beck, R., Lalle, M., Marinculic, A., and Pozio, E. (2008). Multilocus genotyping of Giardia duodenalis reveals striking differences between assemblages $\mathrm{A}$ and B. Int. J. Parasitol. 38, 1523-1531. doi: 10.1016/j.ijpara.2008.04.008

Cao, S., Zhang, Z., Cui, Y., Wang, J., Lv, Y., Li, D., et al. (2015). Survey on the prevalence of intestinal parasites in dairy goats in partial regions of China. J. Henan Agri. Sci. 44, 146-149 (in Chinese). doi: 10.15933/j.cnki.1004-3268.2015.10.033

Chen, J., He, W., Ren, H., Gao, L., and Ning, C. (2015). A survey of prevalence of intestinal parasites in goats in part of the breeding farms of Chongqing. $J$. Southwest Univ. 37, 71-75 (in Chinese). doi: 10.13718/j.cnki.xdzk.2015.03.012

Chen, S. (2001). Two cases of bloody purulent diarrhea caused by Giardia. Mod. Prev. Med. 28:347 (in Chinese).

Chen, X., Lu, S., Li, J., Wang, F., Wang, X., and Wang, F. (2000). Isolation of Hebei isolates of Giardia lamblis and investigation of their genotypes. J. Trop. Dis. Parasitol. 29, 81-84 (in Chinese). doi: 10.3969/j.issn.1672-2302.2000.02.005

Chen, Y., He, L., Jiang, H., and Qiu, X. (2009). Detection of Cryptosporidium and Giardia from raw urban wastewater in Guiyang city. Chin. J. Publ. Health 25:154 (in Chinese). doi: 10.3321/j.issn:1001-0580.2009.02.017

Cooper, M. A., Adam, R. D., Worobey, M., and Sterling, C. R. (2007). Population genetics provides evidence for recombination in Giardia. Curr. Biol. 17, 1984-1988. doi: 10.1016/j.cub.2007.10.020

Cui, P., Ren, Z., Fang, S., and Gu, X. (2010). Diagnosis and treatment of cat giardiasis. Chin J Vet Parasitol. 18, 76-78 (in Chinese). doi: 10.3969/j.issn.1674-6422.2010.02.015

Dobell, C. (1920). The discovery of the intestinal protozoa of man. Proc. R. Soc. Med.. 13, 1-15.

Dong, H., Qi, M., Luo, J., and Zhang, L. (2015). Investigation of intestinal parasites infection in stray dogs in Zhengzhou. Anim. Husb. Vet. Med. 47, 161-162 (in Chinese).

Du, S. Z., Zhao, G. H., Shao, J. F., Fang, Y. Q., Tian, G. R., Zhang, L. X., et al. (2015). Cryptosporidium spp., Giardia intestinalis, and Enterocytozoon bieneusi in captive non-Human primates in Qinling mountains. Korean J. Parasitol. 53, 395-402. doi: 10.3347/kjp.2015.53.4.395

Einarsson, E., Ma'ayeh, S., and Svärd, S. G. (2016). An up-date on Giardia and giardiasis. Curr. Opin. Microbiol. 34, 47-52. doi: 10.1016/j.mib.2016.07.019

Feng, Y., and Xiao, L. (2011). Zoonotic potential and molecular epidemiology of Giardia species and giardiasis. Clin. Microbiol. Rev. 24, 110-140. doi: 10.1128/CMR.00033-10

Franzén, O., Jerlström-Hultqvist, J., Castro, E., Sherwood, E., Ankarklev, J., Reiner, D. S., et al. (2009). Draft genome sequencing of Giardia intestinalis assemblage B isolate GS: is human giardiasis caused by two different species? PLoS Pathog. 5:e1000560. doi: 10.1371/journal.ppat.1000560

Franzén, O., Jerlström-Hultqvist, J., Einarsson, E., Ankarklev, J., Ferella, M., Andersson, B., et al. (2013). Transcriptome profiling of Giardia intestinalis using strand-specific RNA-seq. PLoS Comput. Biol. 9:e1003000. doi: 10.1371/journal.pcbi.1003000

Fu, M., Sun, Q., and Su, L. (2004). Investigation on Giardia lamblia infection among students in Huainan. Chin. J. Sch. Doc. 18, 167-168 (in Chinese). doi: 10.3969/j.issn.1001-7062.2004.02.041

Gabín-García, L. B., Bartolomé, C., Abal-Fabeiro, J. L., Méndez, S., Llovo, J., and Maside, X. (2017). Strong genetic structure revealed by multilocus patterns of variation in Giardia duodenalis isolates of patients from Galicia (NW-Iberian Peninsula). Infect. Genet. Evol. 48, 131-141. doi: 10.1016/j.meegid.2016.12.014

Gan, X., Lin, Q., Yang, Z., Zhong, S., Chen, Y., and Wang, J. (2006). Investigation of intestinal parasite infections in the pupils of Haikou City. J. Hainan Med. Univ. 12, 519-521 (in Chinese). doi: 10.3969/j.issn.1007-1237.2006.06.009

Gao, J., Mao, J., Li, Y., and Hu, C. (2009). A case report of canis giardiasis. Chin. Anim. Husb. Vet. Med. 36, 171-172 (in Chinese).

Gu, Y. F., Wang, K., Liu, D. Y., Mei, N., Chen, C., Chen, T., et al. (2015). Molecular detection of Giardia lamblia and Cryptosporidium species in pet dogs. Chin. J. Parasitol. Paras. Dis. 33, 362-367 (in Chinese).

Gu, Y. F., Wang, L. K., Li, Y., Li, L., Chu, X. H., Xin, D. W., et al. (2014). Prevalence and molecular characterization of Giardia lamblia isolates from goats in Anhui province. Chin. J. Parasitol. Paras. Dis. 32, 401-403 (in Chinese).

Guy, R. A., Payment, P., Krull, U. J., and Horgen, P. A. (2003). Real-time PCR for quantification of Giardia and Cryptosporidium in environmental water samples and sewage. Appl. Environ. Microbiol. 69, 5178-5185. doi: 10.1128/AEM.69.9.5178-5185.2003

He, H., Zhang, X., and Yu, J. (2000). Diagnosis and treatment of dog giardiasis. Vet. Sci. China 30, 44-45 (in Chinese). doi: 10.3969/j.issn.1673-4696.2000.12.023

He, H., Zhang, X., Yu, J., and Chen, J. (2001). A survey of canis Giardia infection on Jilin province. Heilongjiang J Animal Sci Vet Med. 11:19 (in Chinese). doi: 10.3969/j.issn.1004-7034.2001.11.012

He, H., Zhang, X., Yu, J., and Chen, J. (2002). Isolation and differentiation of canis Giardia cysts. Chin. J. Vet. Parasitol. 10, 61-62 (in Chinese). doi: 10.3969/j.issn.1674-6422.2002.02.025

Himsworth, C. G., Skinner, S., Chaban, B., Jenkins, E., Wagner, B. A., Harms, N. J., et al. (2010). Multiple zoonotic pathogens identified in canine feces collected from a remote Canadian indigenous community. Am. J. Trop. Med. Hyg. 83, 338-341. doi: 10.4269/ajtmh.2010.10-0137

Hu, L., Qi, M., Peng, G., Zhong, Z., Dong, H., Zhang, L., et al. (2011). Investigation of intestinal parasites infection in stray dogs in Yàn. Anim. Husb. Vet. Med. 43, 76-77 (in Chinese).

Huang, J., Yue, D., Qi, M., Wang, R., Zhao, J., Li, J., et al. (2014). Prevalence and molecular characterization of Cryptosporidium spp. and Giardia duodenalis in dairy cattle in Ningxia, northwestern China. BMC Vet. Res. 10:292. doi: 10.1186/s12917-014-0292-6

Jerlström-Hultqvist, J., Franzén, O., Ankarklev, J., Xu, F., Nohýnkov,á, E., Andersson, J. O., et al. (2010). Genome analysis and comparative genomics of a Giardia intestinalis assemblage E isolate. BMC Genomics 11:543. doi: 10.1186/1471-2164-11-543

Johnston, A. R., Gillespie, T. R., Rwego, I. B., McLachlan, T. L., Kent, A. D., and Goldberg, T. L. (2010). Molecular epidemiology of cross-species Giardia duodenalis transmission in western Uganda. PLoS Negl. Trop. Dis. 4:e683. doi: 10.1371/journal.pntd.0000683

Karanis, P., Kourenti, C., and Smith, H. (2007). Waterborne transmission of protozoan parasites: a worldwide review of outbreaks and lessons learnt. $J$. Water Health. 5, 1-38. doi: 10.2166/wh.2006.002

Karim, M. R., Wang, R., Yu, F., Li, T., Dong, H., Li, D., et al. (2015). ulti-locus analysis of Giardia duodenalis from nonhuman primates kept in zoos in China: geographical segregation and host-adaptation of assemblage B isolates. Infect. Genet. Evol. 30, 82-88. doi: 10.1016/j.meegid.2014.12.013

Karim, M. R., Zhang, S., Jian, F., Li, J., Zhou, C., Zhang, L., et al. (2014). Multilocus typing of Cryptosporidium spp. and Giardia duodenalis from non-human primates in China. Int. J. Parasitol. 44, 1039-1047. doi: 10.1016/j.ijpara.2014.07.006

Koehler, A. V., Haydon, S. R., Jex, A. R., and Gasser, R. B. (2016). Cryptosporidium and Giardia taxa in faecal samples from animals in catchments supplying the city of Melbourne with drinking water (2011 to 2015). Parasit. Vectors 9:315. doi: 10.1186/s13071-016-1607-1

Lebbad, M., Mattsson, J. G., Christensson, B., Ljungström, B., Backhans, A., Andersson, J. O., et al. (2010). From mouse to moose: multilocus genotyping of Giardia isolates from various animal species. Vet. Parasitol. 168, 231-239. doi: 10.1016/j.vetpar.2009.11.003

Li, F., Wang, H., Zhang, Z., Li, J., Wang, C., Zhao, J., et al. (2016). Prevalence and molecular characterization of Cryptosporidium spp. and Giardia duodenalis in dairy cattle in Beijing, China. Vet. Parasitol. 219, 61-65. doi: 10.1016/j.vetpar.2016.01.023

Li, J., Dong, H., Wang, R., Yu, F., Wu, Y., Chang, Y., et al. (2017). An investigation of parasitic infections and review of molecular characterization of the intestinal protozoa in nonhuman primates in China from 2009 to 2015. Int. J. Parasitol. Parasites Wildl. 6, 8-15. doi: 10.1016/j.ijppaw.2016.12.003

Li, J., Qi, M., Chang, Y., Wang, R., Li, T., Dong, H., et al. (2015). Molecular characterization of Cryptosporidium spp., Giardia duodenalis, and Enterocytozoon bieneusi in captive wildlife at Zhengzhou zoo, China. J. Eukaryot. Microbiol. 62, 833-839. doi: 10.1111/jeu.12269

Li, J., Quan, C., Shi, W., Zhou, Q., Zhang, H., Huang, W., et al. (2013). Investigation on gastrointestinal parasites in captive-bred Macaca mulatta and Macaca fascicularis in Guangxi. Lab. Anim. Comp. Med. 33, 279-284 (in Chinese). doi: 10.3969/j.issn.1674-5817.2013.04.007

Li, J., Wang, P., Zhang, P., Liu, Y., Guo, J., Meng, X., et al. (2012a). Cloning and sequence analysis of efla gene of Gardia lamblia from dogs. Prog. Vet. Med. 33, 53-56 (in Chinese). doi: 10.3969/j.issn.1007-5038.2012.01.012 
Li, J., Wang, P., Zhang, P., Zhu, H., Guo, J., and Li, G. (2011). Cloning and sequence analysis of bg gene of Giardia lamblia from dogs. Anim. Husb. Vet. Med. 43, 1-3 (in Chinese).

Li, J., Zhang, P., Wang, P., Alsarakibi, M., Zhu, H., Liu, Y., et al. (2012b). Genotype identification and prevalence of Giardia duodenalis in pet dogs of Guangzhou, Southern China. Vet. Parasitol. 188, 368-371. doi: 10.1016/j.vetpar.2012.04.004

Li, M., Peng, Y., Zhu, D., Jian, F., Wang, G., Ma, H., et al. (2013). Survey on the prevalence of intestinal parasites in sheep. Chin. Anim. Husb. Vet. Med. 40, 201-205 (in Chinese). doi: 10.3969/j.issn.1671-7236.2013.04.045

Li, M., Zhu, D., Qi, M., Song, D., Shi, Y., Zhao, Z., et al. (2012). Survey on the prevalence of intestinal parasites in Yaoshan white goat. Chin. Anim. Husb. Vet. Med. 39, 191-194 (in Chinese). doi: 10.3969/j.issn.1671-7236.2012.03.043

Li, N., Xiao, L., Wang, L., Zhao, S., Zhao, X., Duan, L., et al. (2012). Molecular surveillance of Cryptosporidium spp., Giardia duodenalis, and Enterocytozoon bieneusi by genotyping and subtyping parasites in wastewater. PLoS Negl. Trop. Dis. 6:e1809. doi: 10.1371/journal.pntd.0001809

Li, W., Deng, L., Wu, K., Huang, X., Song, Y., Su, H., et al. (2017). Presence of zoonotic Cryptosporidium scrofarum, Giardia duodenalis assemblage A and Enterocytozoon bieneusi genotypes in captive Eurasian wild boars (Sus scrofa) in China: potential for zoonotic transmission. Parasit. Vectors. 10:10. doi: 10.1186/s13071-016-1942-2

Li, W., Li, Y., Song, M., Lu, Y., Yang, J., Tao, W., et al. (2015). Prevalence and genetic characteristics of Cryptosporidium, Enterocytozoon bieneusi and Giardia duodenalis in cats and dogs in Heilongjiang province, China. Vet. Parasitol. 208, 125-134. doi: 10.1016/j.vetpar.2015.01.014

Li, W., Liu, C., Yu, Y., Li, J., Gong, P., Song, M., et al. (2013). Molecular characterization of Giardia duodenalis isolates from police and farm dogs in China. Exp. Parasitol. 135, 223-226. doi: 10.1016/j.exppara.2013.07.009

Li, W., Yu, M., Zhong, Z., Wang, Q., Liu, X., Yu, J., et al. (2016). Isolation and identification of Giardia and Cryptosporidium genotypes from captive wild boars and Xiang pigs in Sichuan province. Vet. Sci. China 9, 1166-1169 (in Chinese).

Liang, C. H., Tsaihong, J. C., Cheng, Y. Y., and Peng, S. Y. (2012). Occurrence and genotype of Giardia cysts isolated from faecal samples of children and dogs and from drinking water samples in an aboriginal area of central Taiwan. Exp. Parasitol. 131, 204-209. doi: 10.1016/j.exppara.2012.04.002

Lim, Y. A., Lai, M. M., Mahdy, M. A., Mat Naim, H. R., and Smith, H. V. (2009a). Molecular detection of Giardia contamination in water bodies in a zoo. Environ. Res. 109, 857-859. doi: 10.1016/j.envres.2009. 07.007

Lim, Y. A., Ramasame, S. D., Mahdy, M. A., Sulaiman, W. Y., and Smith, H. V. (2009b). Detection and molecular characterization of Giardia isolated from recreational lake water in Malaysia. Parasitol. Res. 106, 289-291. doi: 10.1007/s00436-009-1602-y

Liu, A., Ji, H., Wang, E., Liu, J., Xiao, L., Shen, Y., et al. (2011). Molecular identification and distribution of Cryptosporidium and Giardia duodenalis in raw urban wastewater in Harbin, China. Parasitol. Res. 109, 913-918. doi: 10.1007/s00436-011-2333-4

Liu, A., Yang, F., Shen, Y., Zhang, W., Wang, R., Zhao, W., et al. (2014). Genetic analysis of the Gdh and Bg genes of animal-derived Giardia duodenalis isolates in Northeastern China and evaluation of zoonotic transmission potential. PLoS ONE 9:e95291. doi: 10.1371/journal.pone.0095291

Liu, A., Zhang, X., Zhang, L., Wang, R., Li, X., Shu, J., et al. (2012). Occurrence of bovine giardiasis and endemic genetic characterization of Giardia duodenalis isolates in Heilongjiang Province, in the Northeast of China. Parasitol. Res. 111, 655-661. doi: 10.1007/s00436-012-2883-0

Liu, G., Su, Y., Zhou, M., Zhao, J., Zhang, T., Ahmad, W., et al. (2015). Prevalence and molecular characterization of Giardia duodenalis isolates from dairy cattle in northeast China. Exp. Parasitol. 154, 20-24. doi: 10.1016/j.exppara.2015.03.020

Liu, H., Shen, Y., Yin, J., Yuan, Z., Jiang, Y., Xu, Y., et al. (2014). Prevalence and genetic characterization of Cryptosporidium, Enterocytozoon, Giardia and Cyclospora in diarrheal outpatients in China. BMC Infect. Dis. 14:25. doi: 10.1186/1471-2334-14-25

Liu, H., Shen, Y. J., Zhang, Y. M., Wang, B., Liu, H., and Cao, J. P. (2015). Infection and molecular characteristics of Giardia in clinical diarrheal patients. Chin. J. Schisto Control. 27, 152-155 (in Chinese). doi: 10.16250/j.32.1374.2014247
Liu, J., Jin, X., Yang, K., Xu, J., Qian, Y., Yan, W., et al. (2016). Epidemiological survey on intestinal parasitic infections in Lhasa city in 2014. Chin. J. Parasitol. Paras. Dis. 34, 405-408 (in Chinese).

Lobo, M. L., Xiao, L., Antunes, F., and Matos, O. (2009). Occurrence of Cryptosporidium and Giardia genotypes and subtypes in raw and treated water in Portugal. Lett. Appl. Microbiol. 48, 732-737. doi: 10.1111/j.1472-765X.2009.02605.x

Lv, C., Feng, C., Qi, M., Yang, H. Y., Jian, F. C., Ning, C. S., et al. (2009a). Investigation on the prevalence of gastrointestinal parasites in pet hamsters. Chin. J. Parasitol. Paras. Dis. 27, 279-280 (in Chinese).

Lv, C., Wang, H., Qi, M., and Zhang, L. (2009b). Survey of intestinal parasites in pet Chinchilla lanigera. Chin. Anim. Husb. Vet. Med. 36, 176-177 (in Chinese).

Lv, S., Tian, L. G., Liu, Q., Qian, M. B., Fu, Q., Steinmann, P., et al. (2013). Water-related parasitic diseases in China. Int. J. Environ. Res. Public Health 10, 1977-2016. doi: 10.3390/ijerph10051977

Ma, L., Sotiriadou, I., Cai, Q., Karanis, G., Wang, G., Wang, G., et al. (2014). Detection of Cryptosporidium and Giardia in agricultural and water environments in the Qinghai area of China by IFT and PCR. Parasitol. Res. 113, 3177-3184. doi: 10.1007/s00436-014-3979-5

Mohammed Mahdy, A. K., Surin, J., Wan, K. L., Mohd-Adnan, A., AlMekhlafi, M. S., and Lim, Y. A. (2009). Giardia intestinalis genotypes: risk factors and correlation with clinical symptoms. Acta Trop. 112, 67-70. doi: 10.1016/j.actatropica.2009.06.012

Mahmoudi, M. R., Nazemalhosseini-Mojarad, E., and Karanis, P. (2015). Genotyping of Giardia lamblia and Entamoeba spp. from river waters in Iran. Parasitol Res. 114, 4565-4570. doi: 10.1007/s00436-015-4702-x

Minetti, C., Taweenan, W., Hogg, R., Featherstone, C., Randle, N., Latham, S. M., et al. (2014). Occurrence and diversity of Giardia duodenalis assemblages in livestock in the UK. Transbound. Emerg. Dis. 61:e60-e67. doi: 10.1111/tbed.12075

Monis, P. T., Andrews, R. H., Mayrhofer, G., and Ey, P. L. (2003). Genetic diversity within the morphological species Giardia intestinalis and its relationship to host origin. Infect. Genet. Evol. 3, 29-38. doi: 10.1016/S1567-1348(02)00149-1

Monis, P. T., Caccio, S. M., and Thompson, R. C. (2009).Variation in Giardia: towards a taxonomic revision of the genus. Trends Parasitol. 25, 93-100. doi: 10.1016/j.pt.2008.11.006

Morrison, H. G., McArthur, A. G., Gillin, F. D., Aley, S. B., Adam, R. D., Olsen, G. J., et al. (2007). Genomic minimalism in the early diverging intestinal parasite Giardia lamblia. Science 317, 1921-1926. doi: 10.1126/science.1143837

Moss, J. A. (2016). Waterborne pathogens: The protozoans. Radiol. Technol. 88, 27-48.

Nolan, M. J., Jex, A. R., Koehler, A. V., Haydon, S. R., Stevens, M. A., and Gasser, R. B. (2013). Molecular-based investigation of Cryptosporidium and Giardia from animals in water catchments in southeastern Australia. Water Res. 47, 1726-1740. doi: 10.1016/j.watres.2012.12.027

Nolan, M. J., Jex, A. R., Pangasa, A., Young, N. D., Campbell, A. J., Stevens, M., et al. (2010). Analysis of nucleotide variation within the triose-phosphate isomerase gene of Giardia duodenalis from sheep and its zoonotic implications. Electrophoresis 31, 287-298. doi: 10.1002/elps.200900480

Pantchev, N., Broglia, A., Paoletti, B., Globokar Vrhovec, M., Bertram, A., Nöckler, K., et al. (2014). Occurrence and molecular typing of Giardia isolates in pet rabbits, chinchillas, guinea pigs and ferrets collected in Europe during 2006-2012. Vet. Rec. 175, 18. doi: 10.1136/vr.102236

Peng, X. Q., Tian, G. R., Ren, G. J., Yu, Z. Q., Lok, J. B., Zhang, L. X., et al. (2016). Infection rate of Giardia duodenalis, Cryptosporidium spp. and Enterocytozoon bieneusi in cashmere, dairy and meat goats in China. Infect. Genet. Evol. 41, 26-31. doi: 10.1016/j.meegid.2016.03.021

Petersen, H. H., Jianmin, W., Katakam, K. K., Mejer, H., Thamsborg, S. M., Dalsgaard, A., et al. (2015). Cryptosporidium and Giardia in Danish organic pig farms: seasonal and age-related variation in prevalence, infection intensity and species/genotypes. Vet. Parasitol. 214, 29-39. doi: 10.1016/j.vetpar.2015.09.020

Poxleitner, M. K., Carpenter, M. L., Mancuso, J. J., Wang, C. J., Dawson, S. C., and Cande, W. Z. (2008). Evidence for karyogamy and exchange of genetic material in the binucleate intestinal parasite Giardia intestinalis. Science 319, 1530-1533. doi: 10.1126/science.1153752

Qi, M., Cai, J., Wang, R., Li, J., Jian, F., Huang, J., et al. (2015a). Molecular characterization of Cryptosporidium spp. and Giardia duodenalis from 
yaks in the central western region of China. BMC Microbiol. 15:108. doi: 10.1186/s12866-015-0446-0

Qi, M., Dong, H., Wang, R., Li, J., Zhao, J., Zhang, L., et al. (2016a). Infection rate and genetic diversity of Giardia duodenalis in pet and stray dogs in Henan Province, China. Parasitol. Int. 65, 159-162. doi: 10.1016/j.parint.2015.11.008

Qi, M., Wang, H., Jing, B., Wang, R., Jian, F., Ning, C., et al. (2016b). Prevalence and multilocus genotyping of Giardia duodenalis in dairy calves in Xinjiang, Northwestern China. Parasit. Vectors. 9, 546. doi: 10.1186/s13071-016-1828-3

Qi, M., Wang, Q., Sun, Y., Dong, H., Zhang, J., Wang, H., et al. (2010a). Investigation of intestinal parasites in pet dogs and its public health significance. Anim. Husb. Vet. Med. 42, 81-83 (in Chinese).

Qi, M., Wang, Q., Zhang, M., Sun, Y., Dong, H., Jian, F., et al. (2011). Epidemiological survey of canis Giardia in dogs in Zhengzhou. Anim. Husb. Vet. Med. 43, 69-71 (in Chinese).

Qi, M., Xi, J., Li, J., Wang, H., Ning, C., and Zhang, L. (2015b). Prevalence of Zoonotic Giardia duodenalis assemblage B and first identification of assemblage $\mathrm{E}$ in rabbit fecal samples isolates from Central China. J. Eukaryot. Microbiol. 62, 810-814. doi: 10.1111/jeu.12239

Qi, M., Xi, J., Lv, C., Zhao, Z., Jian, F., Zhang, L., et al. (2010b). Investigation of Giardia infection in rodents. Chin. J. Zoono. 26, 613-614 (in Chinese). doi: 10.3969/j.issn.1002-2694.2010.06.028

Qi, M., Yu, F., Li, S., Wang, H., Luo, N., Huang, J., et al. (2015c). Multilocus genotyping of potentially zoonotic Giardia duodenalis in pet chinchillas (Chinchilla lanigera) in China. Vet. Parasitol. 208, 113-117. doi: 10.1016/j.vetpar.2015.02.001

Qi, M., Zhou, H., Wang, H., Wang, R., Xiao, L., Arrowood, M. J., et al. (2015d). Molecular identification of Cryptosporidium spp. and Giardia duodenalis in grazing horses from Xinjiang, China. Vet. Parasitol. 209, 169-172. doi: 10.1016/j.vetpar.2015.02.030

Quan, Z., Chen, B., Zheng, B., Ma, X., Lv, C., and Liang, Y. (2016). Investigation on the parasite species and infection situation of 477 cases of outpatient dogs. Prog. Vet. Med. 37, 118-122 (in Chinese). doi: 10.3969/j.issn.1007-5038.2016.11.027

Robertson, L. J., Forberg, T., Hermansen, L., Hamnes, I. S., and Gjerde, B. (2007). Giardia duodenalis cysts isolated from wild moose and reindeer in Norway: genetic characterization by PCR-rflp and sequence analysis at two genes. $J$. Wildl. Dis. 43, 576-585. doi: 10.7589/0090-3558-43.4.576

Ryan, U., and Cacciò, S. M. (2013). Zoonotic potential of Giardia. Int. J. Parasitol. 43, 943-956. doi: 10.1016/j.ijpara.2013.06.001

Shen, H., Zhang, J., Li, Y., Xie, S., Jiang, Y., Wu, Y., et al. (2016). The 12 gastrointestinal pathogens spectrum of acute infectious diarrhea in a sentinel Hospital, Shenzhen, China. Front. Microbiol. 7:1926. doi: 10.3389/fmicb.2016.01926

Shi, K., Ren, X., Wang, Q., Qi, M., An, C., Chen, L., et al. (2010). Investigation of intestinal parasites infection in rabbits in Henan province. Anim. Husb. Vet. Med. 42, 68-70 (in Chinese).

Soliman, R. H., Fuentes, I., and Rubio, J. M. (2011). Identification of a novel Assemblage B subgenotype and a zoonotic Assemblage C in human isolates of Giardia intestinalis in Egypt. Parasitol. Int. 60, 507-511. doi: 10.1016/j.parint.2011.09.006

Song, G. Y., Qin, S. Y., Zhao, G. H., Zhu, X. Q., Zhou, D. H., and Song, M. X. (2016). Molecular characterization of Giardia duodenalis from white yaks in China. Acta Parasitol. 61, 397-400. doi: 10.1515/ap-2016-0052

Sprong, H., Caccio, S. M., and van der Giessen, J. W. (2009). Identification of zoonotic genotypes of Giardia duodenalis. PLoS Negl. Trop. Dis. 3:e558. doi: 10.1371/journal.pntd.0000558

Squire, S. A., and Ryan, U. (2017). Cryptosporidium and Giardia in Africa: current and future challenges. Parasit. Vectors 10:195. doi: 10.1186/s13071-017-2111-y

Sui, P., Li, J., Qi, M., Yu, F., Luo, N., and Ning, C. (2015). Investigation on intestinal parasitic infections in sheep and goat in Anyang, China. Anim. Husb. Vet. Med. 47, 123-126 (in Chinese).

Sulaiman, I. M., Fayer, R., Bern, C., Gilman, R. H., Trout, J. M., Schantz, P. M., et al. (2003). Triosephosphate isomerase gene characterization and potential zoonotic transmission of Giardia duodenalis. Emerging Infect. Dis. 9, 1444-1452. doi: 10.3201/eid0911.030084

Sun, B., Xia, Y., Chen, X., Lai, W., He, C., Ding, Z., et al. (2014). Survey on Cryptosporidium and Giardia in rural central water supply of southern China. J. Public Health Prev. Med. 25, 11-13 (in Chinese).
Sun, Y., Xi, J., Yao, H., Xu, J., Wang, H., Wang, Q., et al. (2010). The prevalence of intestinal parasites of inpatients in a hospital in Zhengzhou city, Henan province. J. Trop. Med. 10, 563-566 (in Chinese).

Tian, L. G., Chen, J. X., Wang, T. P., Cheng, G. J., Steinmann, P., Wang, F. F., et al. (2012). Co-infection of HIV and intestinal parasites in rural area of China. Parasit. Vectors 5:36. doi: 10.1186/1756-3305-5-36

Tseng, Y. C., Ho, G. D., Chen, T. T. W., Huang, B. F., Cheng, P. C., Chen, J. L., et al. (2014). Prevalence and genotype of Giardia duodenalis from faecal samples of stray dogs in Hualien city of eastern Taiwan. Trop. Biomed. 31, 305-311.

Vasilopulos, R. J., Rickard, L. G., Mackin, A. J., Pharr, G. T., and Huston, C. L. (2007). Genotypic analysis of Giardia duodenalis in domestic cats. J. Vet. Intern. Med. 21, 352-355. doi: 10.1111/j.1939-1676.2007.tb02974.x

Volotão, A. C., Costa-Macedo, L. M., Haddad, F. S., Brandão, A., Peralta, J. M., and Fernandes, O. (2007). Genotyping of Giardia duodenalis from human and animal samples from Brazil using beta-giardin gene: a phylogenetic analysis. Acta Trop. 102, 10-19. doi: 10.1016/j.actatropica.2007.02.010

Wang, C., Zhang, Z., Li, J., Yu, F., Cao, J., and Zhang, L. (2016). The investigation of infection and multilocus sequence of Giardia duodenalis in dairy cattle from an imported farm. Acta Vet. Zootech. Sin. 47, 165-171 (in Chinese). doi: 10.11843/j.issn.0366-6964.2016.01.022

Wang, G., Cai, Q., Wang, G., Lu, Y., Li, X., Ye, C., et al. (2013). Detection of Giardia in dog feces in Haiyan county of Qinghai province. Prog. Vet. Med. 34, 29-32 (in Chinese).

Wang, G., Li, X., Wang, G., Cai, Q., and Ma, L. (2016a). Identification and molecular characterization of yak-derived Giardia species in Qinghai province. Prog. Vet. Med. 37, 15-18 (in Chinese). doi: 10.3969/j.issn.1007-5038.2016.08.004

Wang, G., Wang, G. P., Li, X. P., Ma, L. Q., Karanis, G., Christodoulou-Vafeiadou, E., et al. (2017). Detection of Giardia duodenalis assemblage E infections at the Tibetan Plateau Area: yaks are suitable hosts. Acta Trop. 169, 157-162. doi: 10.1016/j.actatropica.2017.02.018

Wang, G., Wang, G., Li, X., Cai, Q., Ma, L., and Zhou, J. (2016b). Detection and genotyping of Giardia isolates from yaks in haibei area of Qinghai province. Progr. Vet. Med. 37, 30-33 (in Chinese). doi: 10.3969/j.issn.1007-5038.2016.07.006

Wang, H., Qi, M., Li, A., Luo, N., Zhou, H., and Wang, M. (2014a). Investigation of intestinal parasites infection in dairy cattle in Kaifeng, China. Anim. Husbl. Vet. Med. 46, 84-87 (in Chinese).

Wang, H., Qi, M., Zhang, K., Li, J., Huang, J., Ning, C., et al. (2016). Prevalence and genotyping of Giardia duodenalis isolated from sheep in Henan Province, central China. Infect. Genet. Evol. 39, 330-335. doi: 10.1016/j.meegid.2016.02.006

Wang, H., Zhao, G., Chen, G., Jian, F., Zhang, S., Feng, C., et al. (2014b). Multilocus genotyping of Giardia duodenalis in dairy cattle in Henan, China. PLoS ONE 9:e100453. doi: 10.1371/journal.pone.0100453

Wang, L., Xiao, L., Duan, L., Ye, J., Guo, Y., Guo, M., et al. (2013). Concurrent infections of Giardia duodenalis, Enterocytozoon bieneusi, and Clostridium difficile in children during a cryptosporidiosis outbreak in a pediatric hospital in China. PLoS Negl. Trop. Dis. 7:e2437. doi: 10.1371/journal.pntd.0002437

Wang, Q., Zhou, Y., Lv, B., Fu, K., Chen, L., Wang, Y., et al. (2009). Prevalence of intestinal parasite infection in Kaifeng city, Henan province. J. Trop. Med. 9, 510-514 (in Chinese).

Wang, R., Zhang, X., Zhu, H., Zhang, L., Feng, Y., Jian, F., et al. (2011). Genetic characterizations of Cryptosporidium spp. and Giardia duodenalis in humans in Henan, China. Exp Parasitol. 127, 42-45. doi: 10.1016/j.exppara.2010.06.034

Wang, T., Fan, Y., Koehler, A. V., Ma, G., Li, T., Hu, M., et al. (2017). First survey of Cryptosporidium, Giardia and Enterocytozoon in diarrhoeic children from Wuhan, China. Infect. Genet. Evol. 51, 127-131. doi: 10.1016/j.meegid.2017.03.006

Wang, X. T., Wang, R. J., Ren, G. J., Yu, Z. Q., Zhang, L. X., Zhang, S. Y., et al. (2016). Multilocus genotyping of Giardia duodenalis and Enterocytozoon bieneusi in dairy and native beef (Qinchuan) calves in Shaanxi province, northwestern China. Parasitol. Res. 115, 1355-1361. doi: 10.1007/s00436-016-4908-6

Wang, Y., Sun, B., and Yu, S. (2015). Investigation on species and infective status of enteroparasites of scattered dogs in a town of Huxian. Prog. Vet. Med. 36, 130-132 (in Chinese). doi: 10.3969/j.issn.1007-5038.2015.03.031 
Wegayehu, T., Karim, M. R., Li, J., Adamu, H., Erko, B., Zhang, L., et al. (2016). Multilocus genotyping of Giardia duodenalis isolates from children in Oromia Special Zone, central Ethiopia. BMC Microbiol. 16:89. doi: 10.1186/s12866-016-0706-7

Wielinga, C., Ryan, U., Andrew Thompson, R. C., and Monis, P. (2011). Multilocus analysis of Giardia duodenalis intra-Assemblage B substitution patterns in cloned culture isolates suggests sub-Assemblage B analyses will require multi-locus genotyping with conserved and variable genes. Int. J. Parasitol. 41, 495-503. doi: 10.1016/j.ijpara.2010.11.007

Xi, J., Du, H., Qi, M., Hu, L., Zhang, L., and Ning, C. (2011a). Prevalence of intestinal parasites in pet rabbits. Chin. Anim. Husb. Vet. Med. 38, 238-240 (in Chinese).

Xi, J., Zhang, K., Qi, M., Wu, G., Xu, L., Jian, F., et al. (2011b). Investigation on the Giardia infection of rabbits in intensity farms, Henan. Anim. Husb. Vet. Med. 43, 78-79 (in Chinese)

Xiao, S., Li, G., Wang, B., Li, W., and Wang, Q. (2006). Molecular identification of the first isolate of calf-derived Giardia from mainland of China. Chin. J. Zoono. 22, 861-863 (in Chinese).

Xu, H., Jin, Y., Wu, W., Li, P., Wang, L., Li, N., et al. (2016). Genotypes of Cryptosporidium spp., Enterocytozoon bieneusi and Giardia duodenalis in dogs and cats in Shanghai, China. Parasit. Vectors 9:121. doi: 10.1186/s13071-016-1409-5

Xu, L., Wu, G., Xi, J., Qi, M., Yang, N., Zhang, L., et al. (2011). Prevalence of intestinal parasitic infection in children in a hospitalized children in Zhengzhou. J. Trop. Med. 11, 17-18 (in Chinese).

Ye, J., Xiao, L., Li, J., Huang, W., Amer, S. E., Guo, Y., et al. (2014). Occurrence of human-pathogenic Enterocytozoon bieneusi, Giardia duodenalis and Cryptosporidium genotypes in laboratory macaques in Guangxi, China. Parasitol. Int. 63, 132-137. doi: 10.1016/j.parint.2013.10.007

Ye, J., Xiao, L., Ma, J., Guo, M., Liu, L., and Feng, Y. (2012). Anthroponotic enteric parasites in monkeys in public park, China. Emerging Infect. Dis. 18, 1640-1643. doi: 10.3201/eid1810.120653

Ye, J., Xiao, L., Wang, Y., Guo, Y., Roellig, D. M., and Feng, Y. (2015). Dominance of Giardia duodenalis assemblage A and Enterocytozoon bieneusi genotype BEB6 in sheep in Inner Mongolia, China. Vet. Parasitol. 210, 235-239. doi: 10.1016/j.vetpar.2015.04.011

Yong, T. S., Park, S. J., Hwang, U. W., Yang, H. W., Lee, K. W., Min, D. Y., et al. (2000). Genotyping of Giardia lamblia isolates from humans in China and Korea using ribosomal DNA sequences. J. Parasitol. 86, 887-891. doi: 10.1645/ 0022-3395(2000)086[0887:GOGLIF]2.0.CO;2

Yu, S., Xu, L., Jiang, Z., Xu, S., Han, J., Zhu, Y., et al. (1994). Report on the first nationwide survey of the distribution of human parasites in China. Chin. J. Parasitol. Paras. Dis. 12, 241-247 (in Chinese).

Yuan, Z., Jiang, Y., He, Z., Wang, L., Zhang, R., Cao, J., et al. (2015). Preliminary analysis of Giardia infection in children from rural areas of Chibi city, Hubei province. Int. J. Med. Parasit. Dis. 42, 86-88 (in Chinese). doi: 10.3760/cma.j.issn.1673-4122.2015.02.006

Zhang, C., and Li, Y. (1983). The clinical analysis of 19 giardiasis. Chin. J. Parasitol. Paras. Dis. 1, 62 (in Chinese).

Zhang, J., Su, Y., Bai, G., Wang, C., Gao, Y., Han, F., et al. (2012). Genotype in dentification of Giardia from cattle in part aresa of northeast China. Chin. J. Vet. Sci. 32, 1679-1682 (in Chinese).

Zhang, P., Zhu, H., Li, J., Li, J., Liu, Y., Guo, J., et al. (2011). Genotyping of two strains of Giardia from dogs by tpi gene. Chin. Anim. Husb. Vet. Med. 38, 59-62 (in Chinese)

Zhang, S. X., Zhou, Y. M., Xu, W., Tian, L. G., Chen, J. X., Chen, S. H., et al. (2016). Impact of co-infections with enteric pathogens on children suffering from acute diarrhea in southwest China. Infect. Dis. Poverty 5:64. doi: 10.1186/s40249-016-0157-2

Zhang, W., Ling, H., Zhang, X., Li, Y., Ji, H., Yang, F., et al. (2012a). Molecular identification of Giardia lamblia isolates from raw urban wastewater using the tpi gene. J. Pathog. Biol. 7, 347-348 (in Chinese).

Zhang, W., Shen, Y., Wang, R., Liu, A., Ling, H., Li, Y., et al. (2012b). Cryptosporidium cuniculus and Giardia duodenalis in rabbits: genetic diversity and possible zoonotic transmission. PLoS ONE 7:e31262. doi: 10.1371/journal.pone.0031262
Zhang, W., Zhang, X., Wang, R., Liu, A., Shen, Y., Ling, H., et al. (2012c). Genetic characterizations of Giardia duodenalis in sheep and goats in Heilongjiang Province, China and possibility of zoonotic transmission. PLoS Negl. Trop. Dis. 6:e1826. doi: 10.1371/journal.pntd.0001826

Zhang, X. X., Tan, Q. D., Zhao, G. H., Ma, J. G., Zheng, W. B., Ni, X. T., et al. (2016a). Prevalence, risk factors and multilocus genotyping of Giardia intestinalis in dairy cattle, Northwest China. J. Eukaryot. Microbiol. 63, 498-504. doi: $10.1111 /$ jeu. 12293

Zhang, X. X., Zhang, F. K., Li, F. C., Hou, J. L., Zheng, W. B., Du, S. Z., et al. (2017). The presence of Giardia intestinalis in donkeys, Equus asinus, in China. Parasit. Vectors 10, 3. doi: 10.1186/s13071-016-1936-0

Zhang, X. X., Zheng, W. B., Ma, J. G., Yao, Q. X., Zou, Y., Bubu, C. J., et al. (2016b). Occurrence and multilocus genotyping of Giardia intestinalis assemblage $\mathrm{C}$ and $\mathrm{D}$ in farmed raccoon dogs, Nyctereutes procyonoides, in China. Parasit. Vectors 9, 471. doi: 10.1186/s13071-016-1771-3

Zhang, X. P., He, Y. Y., Zhu, Q., Ma, X. J., and Cai, L. (2010). Investigation on contamination of Cryptosporidium and Giardia in drinking water and environmental water in Shanghai. Chin. J. Parasitol. Paras. Dis. 28, 435-438 (in Chinese).

Zhao, G. H., Du, S. Z., Wang, H. B., Hu, X. F., Deng, M. J., Yu, S. K., et al. (2015). First report of zoonotic Cryptosporidium spp., Giardia intestinalis and Enterocytozoon bieneusi in golden takins (Budorcas taxicolor bedfordi). Infect. Genet. Evol. 34, 394-401. doi: 10.1016/j.meegid.2015.07.016

Zhao, J., Qi, M., Wang, H., Feng, C., and Zhang, L. (2011). Prevalence of intestinal parasites in captive macaques (Macaca mulatt). J. Henan Agric. Sci. 40, 135-138 (in Chinese). doi: 10.3969/j.issn.1004-3268.2011.07.035

Zhao, J., Wang, H., Qi, M., Yu, F., Liu, Q., and Zhang, L. (2016). Prevalence and multilocus genotyping of Giardia duodenalis in dairy cattle in Kaifeng, China. Vet. Sci. China. 4, 496-501 (in Chinese).

Zhao, Z., Wang, R., Zhao, W., Qi, M., Zhao, J., Zhang, L., et al. (2015). Genotyping and subtyping of Giardia and Cryptosporidium isolates from commensal rodents in China. Parasitology 142, 800-806. doi: 10.1017/S0031182014001929

Zheng, G., Alsarakibi, M., Liu, Y., Hu, W., Luo, Q., Tan, L., et al. (2014). Genotyping of Giardia duodenalis isolates from dogs in Guangdong, China based on multi-locus sequence. Korean J. Parasitol. 52, 299-304. doi: $10.3347 /$ kjp.2014.52.3.299

Zheng, G., Hu, W., Liu, Y., Luo, Q., Tan, L., and Li, G. (2015). Occurrence and molecular identification of Giardia duodenalis from stray cats in Guangzhou, southern China. Korean J. Parasitol. 53, 119-124. doi: 10.3347/kjp.2015.53.1.119

Zheng, G., Liu, Y., Li, Y., Hu, W., Lu, P., Lin, L., et al. (2013). Characteristics of cat-derived Giardia by the EFl a and GDH genes. Chin. J. Prev. Vet. Med. 35, 1023-1025 (in Chinese). doi: 10.3969/j.issn.1008-0589.2013.12.17

Zhong, Y., Yang, Y., Du, L., Gan, P., Hou, S., Liu, C., et al. (2010). A survey on the water hygiene condition in Guangzhou. J. Trop. Med. 10, 1436-1438 (in Chinese).

Zhu, D., Lv, Y., Li, M., Zhang, Z., Jian, F., Song, D., et al. (2013). Survey on the prevalence of intestinal parasites in goats in partial regions of China China Herb. Sci. 33, 43-46 (in Chinese). doi: 10.3969/j.issn.2095-3887.2013. 01.011

Zhu, D., Wei, J., Qi, M., Li, M., Shi, Y., Du, H., et al. (2012). Investigation on the intestinal parasites infection in large tailed han sheep in Jiaxian, Henan. China Herb. Sci. 32, 69-71 (in Chinese). doi: 10.3969/j.issn.2095-3887.2012.01.022

Zhu, H., Li, G., Zhang, P., Li, J., Li, J., and Lin, Z. (2011). Genotype identification of Giardia from dogs in Guangdong. Vet. Sci. China 41, 143-147 (in Chinese).

Conflict of Interest Statement: The authors declare that the research was conducted in the absence of any commercial or financial relationships that could be construed as a potential conflict of interest.

Copyright (c) 2017 Li, Wang, Wang and Zhang. This is an open-access article distributed under the terms of the Creative Commons Attribution License (CC BY). The use, distribution or reproduction in other forums is permitted, provided the original author(s) or licensor are credited and that the original publication in this journal is cited, in accordance with accepted academic practice. No use, distribution or reproduction is permitted which does not comply with these terms. 